\title{
Intercellular Junction Assembly, Dynamics, and Homeostasis
}

\author{
Kathleen J. Green ${ }^{1}$, Spiro Getsios ${ }^{2}$, Sergey Troyanovsky ${ }^{3}$, and L.M. Godsel ${ }^{1}$ \\ ${ }^{1}$ Northwestern University Feinberg School of Medicine, Departments of Pathology and Dermatology, \\ R.H. Lurie Comprehensive Cancer Center, 303 E. Chicago Ave. Chicago, Illinois 60611 \\ ${ }^{2}$ Departments of Dermatology and Cell and Molecular Biology, R.H. Lurie Comprehensive Cancer Center, \\ 303 E. Chicago Ave., Chicago, Illinois 60611 \\ ${ }^{3}$ Department of Dermatoogy, R.H. Lurie Comprehensive Cancer Center, 303 E. Chicago Ave., Chicago, \\ Illinois 60611 \\ Correspondence: kgreen@northwestern.edu
}

\begin{abstract}
Intercellular anchoring junctions are highly specialized regions of the plasma membrane where members of the cadherin family of transmembrane adhesion molecules on opposing cells interact through their extracellular domains, and through their cytoplasmic domains serve as a platform for organizing cytoskeletal anchors and remodelers. Here we focus on assembly of so-called "anchoring" or "adhering" junctions-adherens junctions (AJs) and desmosomes (DSMs), which associate with actin and intermediate filaments, respectively. We will examine how the assembly and function of AJs and DSMs are intimately connected during embryogenesis and in adult cells and tissues, and in some cases even form specialized "mixed" junctions. We will explore signaling and trafficking machineries that drive assembly and remodeling and how these mechanisms are co-opted in human disease.
\end{abstract}

In multicellular organisms intercellular junctions serve to maintain cell and tissue polarity and integrity. In vertebrates these organelles include: gap junctions, which chemically and electrically couple neighboring cells; tight junctions, which are essential for establishing the epithelial barrier; and "adhering junctions," which organize the cortical cytoskeleton beneath the plasma membrane to modulate cell and tissue behavior. Together, these organelles integrate intra- and intercellular signaling, including regulation of nuclear functions and transcriptional pathways.
Calcium-dependent, cadherin-based anchoring junctions known as adherens junctions (AJs) and desmosomes (DSMs) organize and tether microfilaments and intermediate filaments (IF) to the plasma membrane, respectively. In polarized cells, AJs appear as continuous zonula, subjacent to the tight junctions, and are uniformly distributed along the plasma membrane in a belt that is closely opposed to an actin-rich mat underneath the plasma membrane (Niessen and Gottardi 2008). DSMs appear as "spot welds" distributed subjacent to the zonula and scattered throughout the

Editors: W. James Nelson and Elaine Fuchs

Additional Perspectives on Cell Junctions available at www.cshperspectives.org

Copyright (C) 2010 Cold Spring Harbor Laboratory Press; all rights reserved; doi: 10.1101/cshperspect.a000125

Cite this article as Cold Spring Harb Perspect Biol 2010;2:a000125 


\section{K.J. Green et al.}

lateral border, where they distribute forces of mechanical stress via interactions with the IF cytoskeleton (Holthofer et al. 2007; Garrod and Chidgey 2008). These junction types appeared at different times during the evolution of multicellular organisms, but share common blueprints, linked assembly mechanisms and synergistic functions.

Building Blocks for Assembly of Intercellular Adhering Junctions

The structure of AJs and DSMs is roughly parallel in blueprint and can be broken down into three major components: the (1) transmembrane cadherins, the tails of which provide a scaffold for (2) armadillo family members, which help build a cortical platform for additional (3) cytoskeletal adapter proteins (see also Meng and Takeichi 2009). Together these components associate with and organize actin and IF, respectively, at the plasma membrane.

Cadherins and Nectins: Classical cadherins (e.g., E- and $\mathrm{N}$ - and P-cadherin) are single-pass transmembrane proteins (Hulpiau and van Roy 2009). Their extracellular cadherin domains contain a series of five conserved cadherin repeats, which extend from the cell surfaces and bind to cadherins present on adjacent cells (see Shapiro and Weis 2009). The cytoplasmic domains contain binding sites for associated catenins (see the following discussion) and other regulatory proteins (Perez-Moreno and Fuchs 2006). The desmosomal cadherins, desmogleins and desmocollins, have a similar ectodomain structure but more divergent cytoplasmic domains (Getsios et al. 2004b). In particular, the desmogleins have extended cytoplasmic tails containing variable numbers of RUD (repeating unit domain) motifs, whose function is unknown.

Nectins are more recently identified calcium-independent adhesion molecules in the IgG superfamily (Irie et al. 2004). They are thought to prime adhesive interactions for cadherins, thus initiating AJ assembly. Notably, the nectin cytoplasmic domain interacts with an actin binding protein called afadin/AF6, which has been shown to bind to $\alpha$-catenin and has thus been implicated in recruiting/clustering cadherin complexes in nascent junctions, and as a possible alternative way to link actin to the plasma membrane, as described below (Tachibana et al. 2000).

Armadillo Proteins: Both desmosomal and classic cadherins contain conserved intracellular domains that bind members of the armadillo family (Hatzfeld 2007). Junctional armadillo proteins fall into two subclasses that are each characterized by a central domain built from a series of $\sim 42$ amino acid armadillo repeats. Armadillo drives the transcriptional program responsible for segment polarity in the fly, in addition to being a key component of fly AJs (Brembeck et al. 2006). Intercellular adhering junctions contain members from two armadillo subfamilies: One family contains armadillo and its close relative plakoglobin; the other group contains p120catenin, $\delta$-catenin/NPRAP (neural plakophilin related arm protein, NPRAP), ARVCF (armadillo repeat gene deleted in Velo-Cardio-Facial syndrome), and plakophilins (PKPs) $1-3$ and p0071/PKP4 (Hatzfeld 2007).

Cytoskeletal Adaptor Proteins: The cytoplasmic cadherin tails and associated armadillo proteins are embedded within a cortical meshwork containing cytoskeletal adaptor proteins and associated cytoskeletal fibers that make up the electron dense junctional "plaque." Contained within this plaque region are the $\beta$-catenin binding protein $\alpha$-catenin, and the plakoglobin- and PKP-binding protein desmoplakin (Green and Simpson 2007; Niessen and Gottardi 2008). In previous textbook models, these adaptors are final links in a chain that connect cadherins to their respective cytoskeletons, actin and IF. However, cadherin$\beta-\alpha$-catenin and $\alpha$-catenin-actin interactions have recently been shown to be mutually exclusive in vitro (Yamada et al. 2005). Thus, the identity or identities of the real actin anchors are uncertain. $\alpha$-Catenin may still contribute to the effort indirectly via associated proteins such as afadin, $\alpha$-actinin, vinculin, ZO-1, or EPLIN (Abe and Takeichi 2008; Stemmler 2008). Data from AJ studies also prompt new consideration of the model proposed for 
DSMs, whereby desmoplakin directly links IF to the desmosomal cadherin complex.

These core junctional components are assisted by additional cell-type specific and accessory molecules including actin remodeling proteins, IF binding and cornified envelope proteins, tyrosine kinases and phosphatases, growth factor receptors, and their associated proteins, which cooperate to tailor junctions structurally and functionally (Perez-Moreno and Fuchs 2006; Holthofer et al. 2007).

\section{EMBRYOGENESIS AND JUNCTION ASSEMBLY}

\section{An Evolutionary Perspective}

The cadherin superfamily comprises over one hundred members (Hulpiau and van Roy 2009). Cadherins first appeared in single-celled organisms, such as the choanoflagellate Monosiga brevicollis, where they are speculated to have served a role in binding bacterial prey (Abedin and King 2008; King et al. 2008). With the acquisition of multicellularity, cadherins recruited other structural and signaling proteins into primitive AJs. This ancient "assembly" step advanced AJ functions in regulating tissue morphogenesis through junctional and nonjunctional pathways, the latter through armadillo proteins that moved between the surface and the nucleus (Grimson et al. 2000; Schneider et al. 2003). With the appearance of vertebrates came the desmosomal cadherins. Their expanded diversity allowed tailoring of adhesive junctions for new structural and morphogenetic requirements, providing complex tissues with mechanical integrity whose importance is underscored by human diseases of the desmosome and corresponding animal models (reviewed by Kowalczyk and colleagues [Delva et al. 2009]) (Cheng and Koch 2004; Lai-Cheong et al. 2007). Consistent with the mantra "ontogeny recapitulates phylogeny," AJs appear first during embryonic development. A rich body of literature regards AJs as master regulators of TJ and DSM assembly, suggesting that their assembly routes may have been overlaid on pre-existing cytoskeletal and signaling pathways.

De Novo Junction Assembly in the Preimplantation Embryo

Intercellular junctions are initially formed during compaction of the 8-cell stage embryo in a process that culminates with the differentiation of the first epithelial layer, the trophectoderm (Fig. 1) (Vestweber et al. 1987; Fleming et al. 1991; Fleming et al. 1993; Barcroft et al. 1998). Up until the early 8-cell stage, the embryo consists of loosely adherent blastomeres. On compaction, these relatively spherical blastomeres are converted into highly polarized cells that flatten to maximize contact points and begin to elaborate AJs along with focal tight and gap junctions (Fleming et al. 1993; Eckert and Fleming 2008). In contrast, DSMs anchoring intermediate filaments to cell-cell contacts are only found in the mature trophectodermal epithelium at the 32-cell stage when a blastocoel cavity has formed and tight junctions have adopted a more zonular distribution. This sequence of developmental events places E-cadherin upstream in a pathway that allows for the formation and organization of other anchoring junctions.

E-cadherin-based adhesion complexes are required for embryo compaction and the subsequent formation of a trophectodermal epithelium (Larue et al. 1994; Riethmacher et al. 1995; Torres et al. 1997; De Vries et al. 2004). The mere presence of E-cadherin or its cytoplasmic partners $(\alpha-, \beta-, \gamma$-catenin $)$ is not sufficient to trigger compaction because all of these proteins are diffusely expressed along the cell surface in blastomeres of 4-cell embryos (Kidder and McLachlin 1985; Vestweber et al. 1987; Fleming et al. 1991; Fleming et al. 1993; Collins et al. 1995; Ohsugi et al. 1996; Barcroft et al. 1998). Although the process that activates the cadherin complex during compaction is not known, PKC $\alpha$ is redistributed to cell-cell contacts in 8-cell blastomeres and its activation can trigger compaction and $\beta$-catenin phosphorylation (Sefton et al. 1992; Pauken and Capco 1999). Because depletion of $\beta$-catenin 
K.J. Green et al.
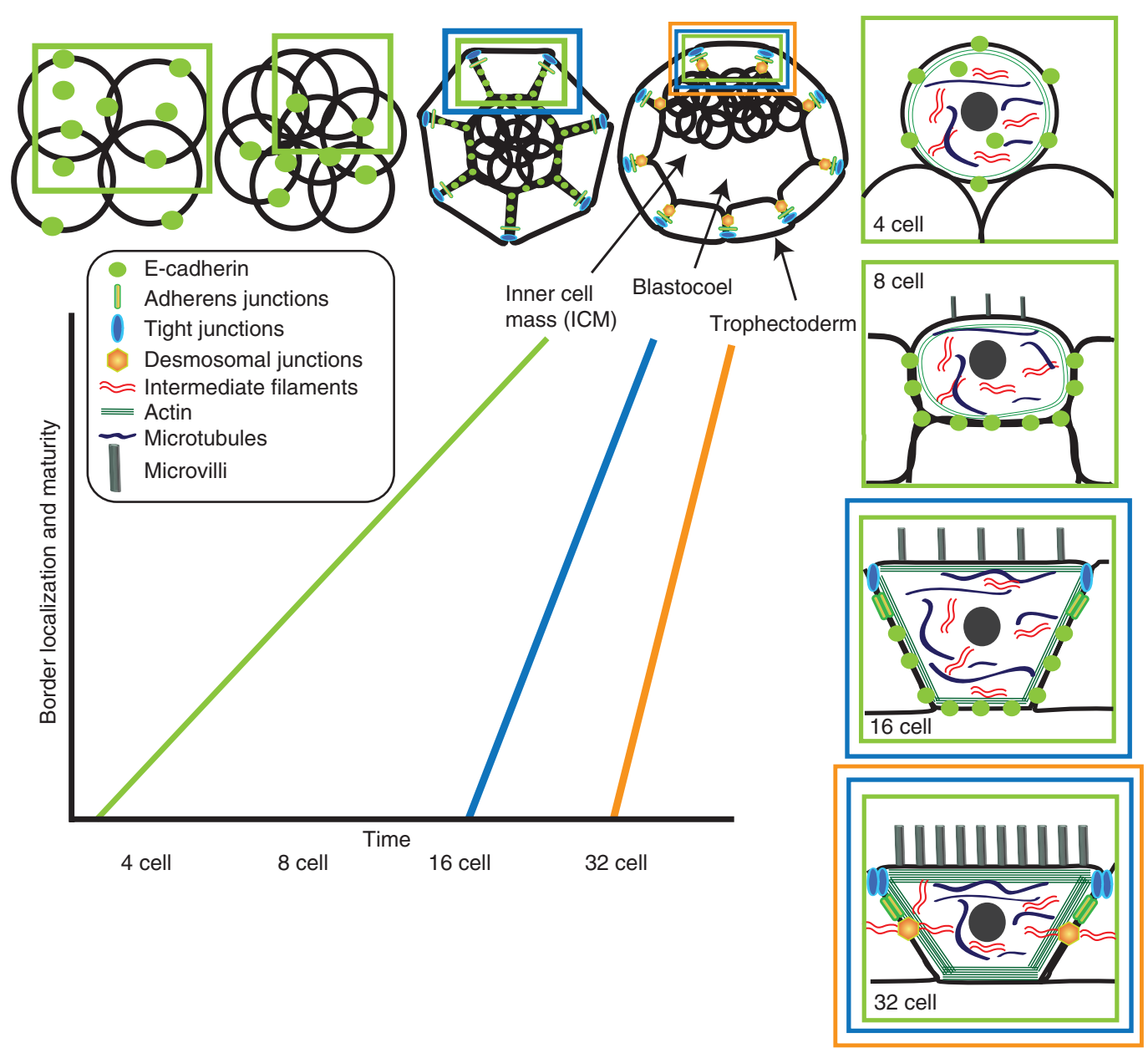

Figure 1. Junction biogenesis in preimplantation mammalian embryos. Following the initial cleavage event of the zygote and throughout the entire 4-cell stage, blastomeres are loosely connected to one another and exhibit a diffuse distribution of E-cadherin. Embryo compaction at the 8-cell stage stabilizes E-cadherin along increasing areas of cell-cell contact and initiates a process of junction assembly, cytoskeletal (actin microfilaments and microtubules) reorganization, and increased polarization of apico-basolateral membrane domains (apical microvilli). Asymmetric cell divisions that give rise to a 16-cell embryo allocate inner daughter cells lacking epithelial characteristics and an outer epithelial cell layer that gradually elaborates actin cytoskeleton-associated adherens and tight junctions (reviewed in Eckert and Fleming 2008). A functional tight junction barrier triggers cavitation and the formation of a fluid-filled blastocoel that contacts the inner cell mass; this process is coordinated with the abrupt assembly of intermediate filament-associated desmosomes in the outer trophectodermal epithelium.

results in postimplantation loss of embryos (Haegel et al. 1995), this armadillo family member is not the only target for PKCmediated compaction events. Vezatin, which bridges the unconventional myosin VIIa motor to the cadherin-catenin complex, is a potential candidate because it maintains the levels of E-cadherin and $\beta$-catenin to allow for compaction (Hyenne et al. 2007). Accordingly, compaction also requires active actin remodeling and contraction (Kabir et al. 1996; Clayton et al. 1999).

Desmosomes form fairly abruptly in the trophectodermal epithelium at the 32-cell stage, in contrast to the more gradual maturation and redistribution of tight junctions 
into a zonular pattern at the apical interface. Although plakoglobin and Dsc3 are present at the time of compaction, most other desmosome proteins, including membrane (Dsg2, Dsc2) and plaque (desmoplakin) components, are first detected in the early blastocyst upon formation of an outer trophectoderm layer that surrounds the inner cell mass (Jackson et al. 1980; Fleming et al. 1991; Den et al. 2006). The induction of Dsc2 mRNA transcripts is tightly coordinated with the appearance of desmosomes and subsequent blastocoel formation (Fleming et al. 1991; Collins et al. 1995). The developmental signal that triggers Dsc2 expression appears to be E-cadherinindependent because Dsc2 and desmoplakin can be induced in the presence of function blocking antibodies for this classical cadherin. Moreover, desmosomal cadherins are normally distributed at the cell surface of E-cadherin-null blastocysts that have undergone compaction owing to the persistence of maternally derived E-cadherin or its ectopic replacement by transgenic N-cadherin expression (Ohsugi et al. 1997; Kan et al. 2007). Although Dsc2 induction appears to be a key initiator of desmosome assembly, E-cadherin is uniquely required for trophectoderm maturation leading to the death of these embryos during the preimplantation stages.

Embryos completely lacking zygotic and maternal E-cadherin cannot form DSMs and never reach the 32-cell stage because of a failure in compaction (De Vries et al. 2004; Kan et al. 2007). These results are mirrored by the observation that depletion of classic cadherins in keratinocytes results in a failure to form DSMs in vitro (Tinkle et al. 2008; Michels et al. 2009). These findings suggest that the temporal pattern of junction assembly is linked to their functional interdependence, a concept that will be further explored in the following section.

\section{IN VITRO ANALYSIS OF CELL JUNCTION ASSEMBLY AND DYNAMICS}

As during evolution and embryogenesis, AJ formation precedes DSM formation in vitro; however, rather than being drawn out over days of embryogenesis, events occur within minutes of de novo cell contact or elevation of extracellular calcium (Figs. 2 and 3). AJs and DSMs exhibit interdependence from the initiation of nascent complexes through segregation of components into specific domains. Functionally, mature junctions synergize to maintain epithelial polarity and integrity. Further, junction homeostasis is a balance of biosynthetic and endocytic pathways, each step subject to post-translational modifications and pathogenic input.

Assembly of the Adherens Junction and Desmosome Adhesive Interface

Trafficking behavior of cadherins and associated armadillo proteins: Desmosomal and classic cadherins are constantly synthesized and delivered to the plasma membrane (Fig. 4) (Penn et al. 1987; Pasdar and Nelson 1989; Shore and Nelson 1991). In response to de novo contact or elevation of extracellular calcium, cadherins cluster and become stabilized, and, in most cell types, segregate into distinct domains.

Cadherins follow a classic secretory route beginning with synthesis in the endoplasmic reticulum (ER), followed by transport to the Golgi for processing, sorting into post-Golgi carriers, and long range trafficking via MT-dependent motors (reviewed in Bryant and Stow 2004). Transport of tubulovesicular carriers containing E-cadherin out of the trans-Golgi network is dependent on the tethering protein Golgin-97 (Lock et al. 2005) and association with ankyrin-G and $\beta$-2-spectrin (Kizhatil et al. 2007). The ankyrin-G-spectrin complex later stabilizes E-cadherin by directly connecting it to the spectrin/actin cytoskeleton (Kizhatil et al. 2007), and these functions are both critical for coordinating cadherin trafficking with formation of cell-cell contacts in both cultured cells and developing embryos (Kizhatil et al. 2007). Studies linking desmosomal PKPs to vesicle trafficking have begun to emerge, with the discovery that PKP3 associates with the dynamin-like protein DNM1L, which is involved in vesicle trafficking within the 
K.J. Green et al.
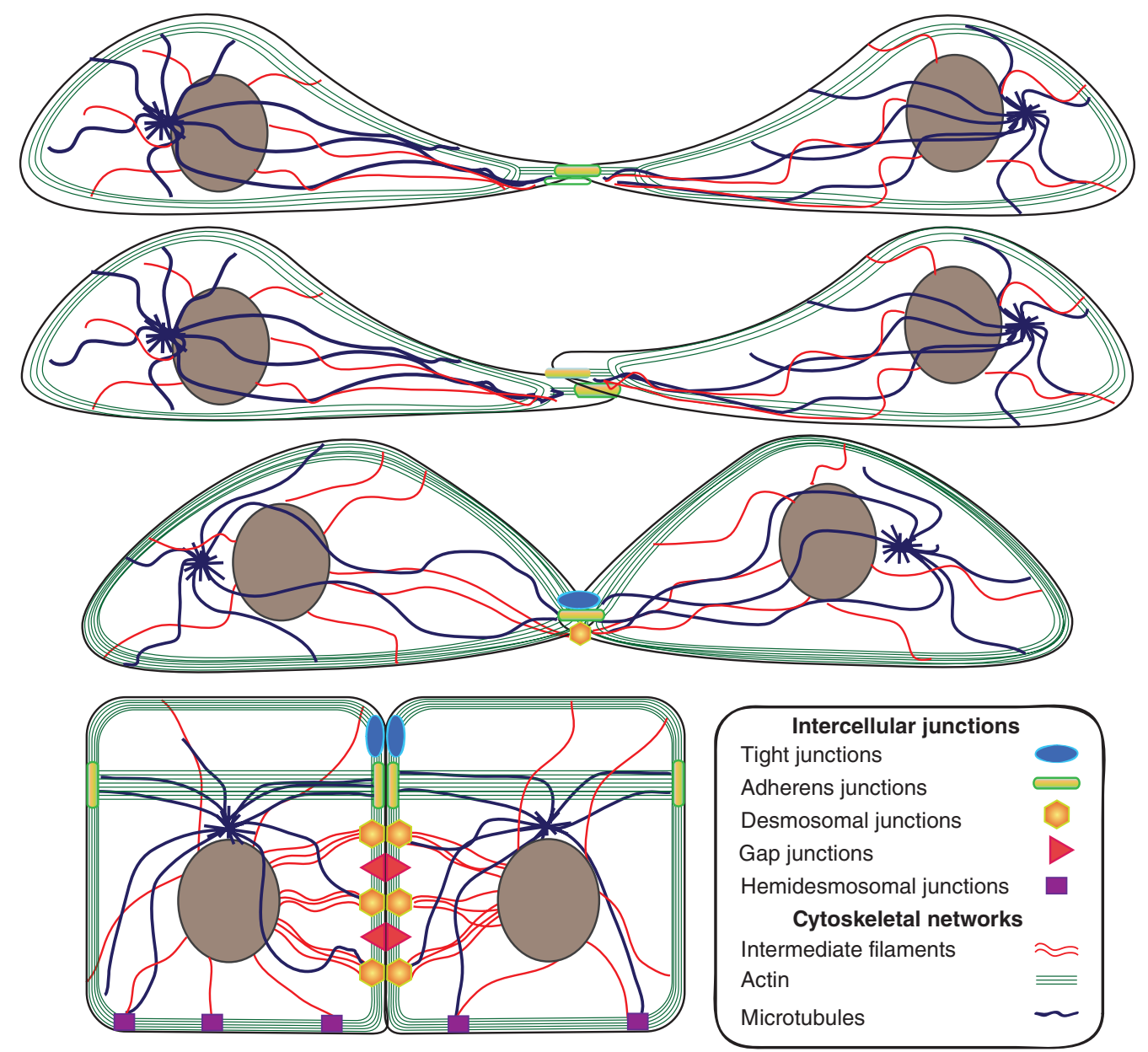

Figure 2. Junction biogenesis in vitro and associated cytoskeletal arrangements. Following cell contact in vitro, initial cadherin engagement triggers reorganization of the cytoskeleton, coordinated with downstream assembly of tight junctions and desmosomes. In polarized simple epithelial cells, the maturation of junctional contacts is accompanied by the formation of a circumferential zone of parallel microfilament bundles near the apical region of the cell, below the tight junction barrier. Desmosomes are subjacent to this complex and also appear as disclike structures that extend along the entire lateral border, where they anchor IF to the plasma membrane. MTs also anchor at AJs and DSMs.

secretory pathway in lung carcinoma cells (Furukawa et al. 2005).

Both classic and desmosomal counterparts are synthesized as precursor propeptides and processed via a furin-dependent mechanism before reaching the cell surface (Muller et al. 2004; Yokouchi et al. 2009). The presence of the propeptide is thought to prevent premature adhesion inside the cell (Ozawa and Kemler 1990). Glycosylation does not appear to be required for efficient processing of the precursor or transport of E-cadherin to the cell surface, but in the case of desmosomal cadherins, may contribute to their notable insolubility (Shore and Nelson 1991).

The E-cadherin tail is unstructured in the absence of its binding partners $\beta$-catenin and p120catenin, which protect it from degradation (Huber et al. 2001; Davis et al. 2003) and shepherd the cadherin from the ER to the plasma membrane (Chen et al. 1999). A soluble pool of plakoglobin, which is capable of associating 
A

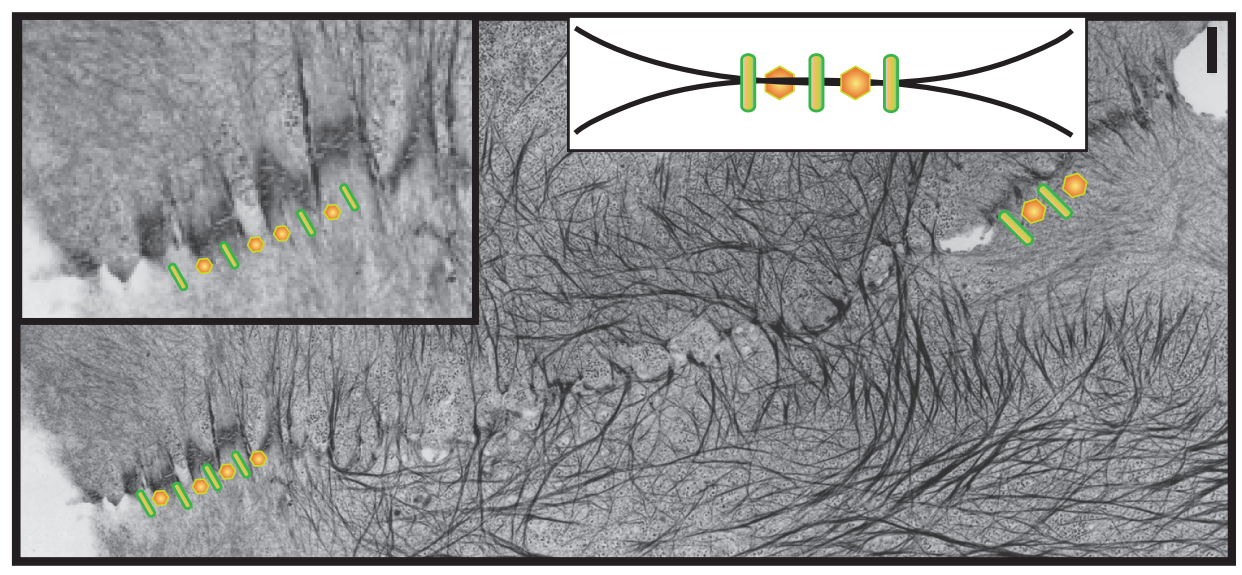

B

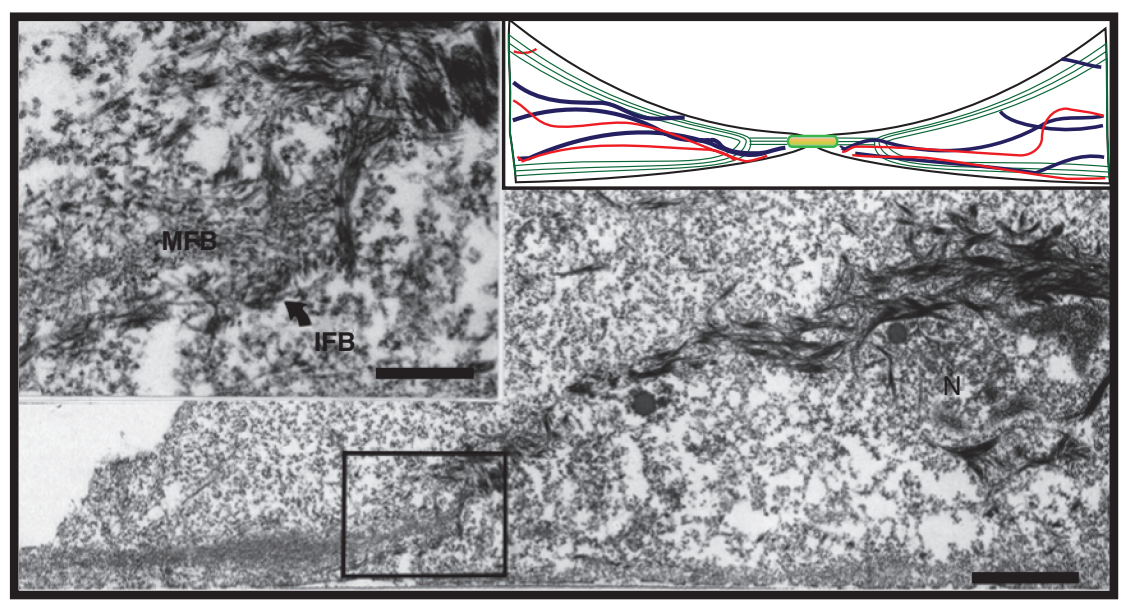

Figure 3. Ultrastructural relationships between microfilaments, IFs, and associated adhering junctions at keratinocyte cell-cell contacts and during contact formation. (A) Transverse section through cell contact zone between two mouse keratinocytes showing alternating arrangement of AJs and DSMs at the cell margins with their associated actin and IF networks. (B) Cross section of mouse keratinocyte during contact initiation shows the intimate connection between keratin IF bundles, which emanate from the nuclear surface and dive down towards and integrate within actin bundles near the substrate (Reprinted, with permission, from Green et al. 1987).

with both classic and desmosomal cadherins, initially associates primarily with E-cadherin and may serve a similar role (Hinck et al. 1994). An insoluble pool of newly synthesized plakoglobin associated with desmoglein is required for its stabilization and incorporation into DSMs (Pasdar et al. 1995). The functional implications of a potential temporal switch in partnership between classic and desmosomal cadherins was indicated by experiments suggesting that desmosome assembly in A431 cells depends on the presence of plakoglobin associated with E-cadherin (Lewis et al. 1997). Whether plakoglobin serves a chaperone role for desmosomal cadherins has not been directly tested, although desmogleins are also unstructured in the absence of plakoglobin binding (Kami et al. 2009), and truncated desmogleins deficient in plakoglobin binding fail to properly localize to plasma membranes (Andl and Stanley 2001).

In polarized epithelial cells, $\alpha$-catenin and p120 associate with E-cadherin as it reaches the plasma membrane (Hinck et al. 1994; 


\section{K.J. Green et al.}
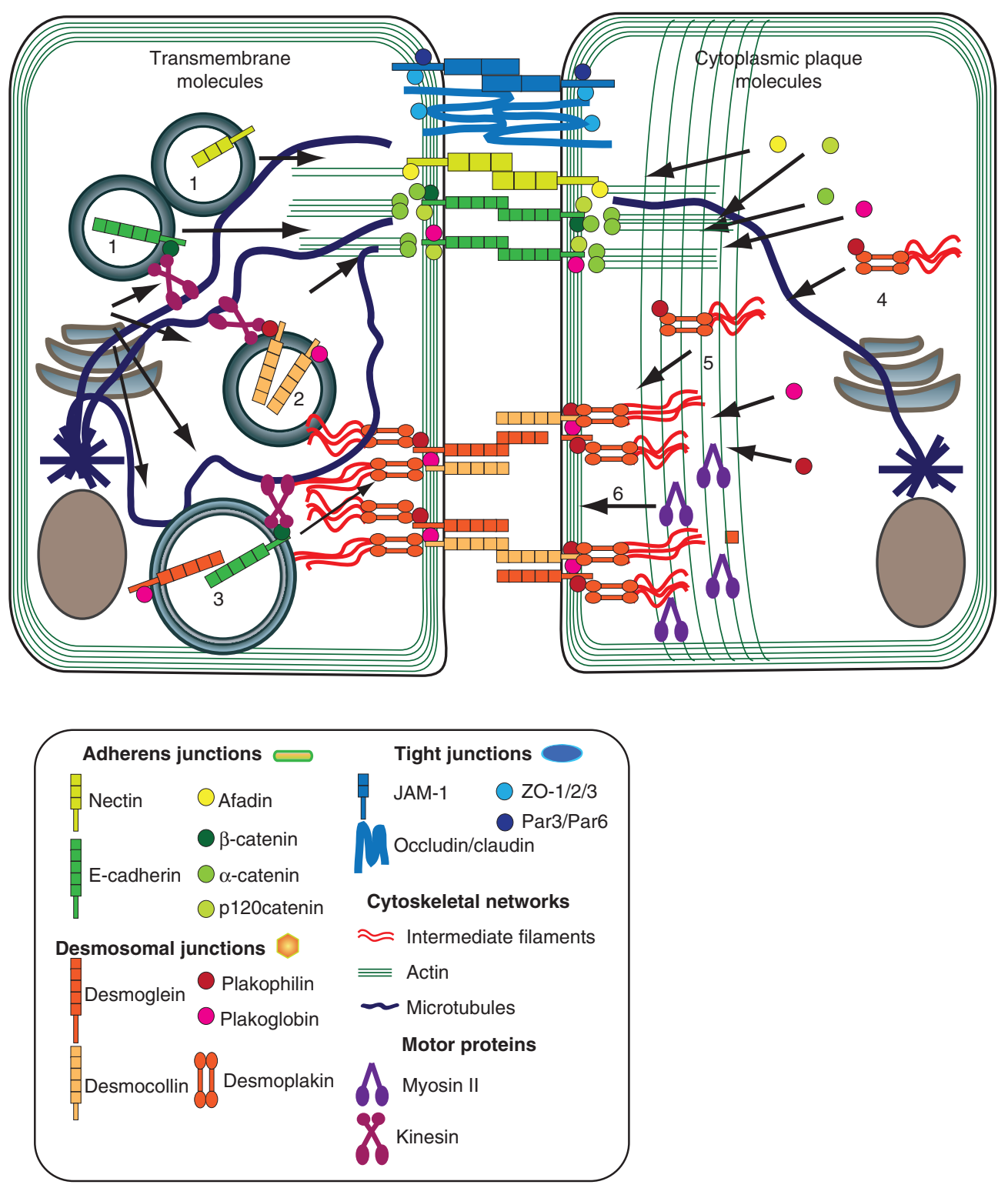

Figure 4. Model depicting possible molecular dynamics of intercellular junction assembly. Molecular players in assembly of the adhesive core (left cell) and junctional plaques (right cell) are depicted, with emphasis on AJs and DSMs assembly. Transmembrane molecules are transported in a MT-dependent fashion toward the plasma membrane, possibly via molecular motors in the kinesin family. Cadherins and nectins (1) initiate the process of assembly of the AJ adhesive interface, whereas initial recruitment of desmocollins (2) is followed by stabilization at sites of junction assembly by desmogleins (3). Cargo loading may be facilitated through armadillo family members in some cases. Junctional plaque assembly occurs through dynamic remodeling of the cortical cytoskeleton, initiated by the cadherin-dependent concentration of actin remodeling proteins at sites of junction assembly to drive actin polymerization and reorganization from branched to bundled actin. In coordination with these changes, desmosomal precursors containing desmoplakin and plakophilin are formed in the cytoplasm in close association with IF. Desmosome precursors (4) subsequently translocate to sites of desmosome assembly in an actomyosin-dependent manner to reinforce the plaque (5), in conjunction with actin rearrangement depending on myosin II (6). 
Intercellular Junction Assembly, Dynamics, and Homeostasis

Miranda et al. 2003). Here p120 promotes junction formation by stabilizing cadherins through interfering with endocytic internalization (Davis et al. 2003; Kowalczyk and Reynolds 2004) and association with the actin-associated protein afadin in a Rap1 GTPase-dependent manner (Hoshino et al. 2005).

\section{Cadherin Dynamics and Role of Microtubules}

Intercellular adhesions depend on the presence of an intact microtubule (MT) cytoskeleton (Grindstaff et al. 1998; Waterman-Storer et al. 2000; Stehbens et al. 2006; Kizhatil et al. 2007; Stehbens et al. 2009). MTs facilitate long-range trafficking of classic and desmosomal cadherins including their anterograde transport to the plasma membrane (Pasdar et al. 1991; Mary et al. 2002; Chen et al. 2003). Evidence is consistent with transport via kinesins, possibly through associated armadillo proteins (Mary et al. 2002; Chen et al. 2003; Teng et al. 2005) (Fig. 4).

Established junctions interact with both plus- and minus-end-directed MTs and associated motor proteins. These interactions regulate junction assembly state and provide transport routes to sites of cell adhesion (Ligon and Holzbaur 2007; Shaw et al. 2007). $\beta$-catenindynein (Ligon et al. 2001), $\alpha$-E-catenindynactin (Lien et al. 2008) and Nezha/ PLEKHA7-KIFC3 (Meng et al. 2008) associations have been revealed as critical for MT interaction and AJ stability. Further, dynamic MTs at adhesion sites promotes active myosin II recruitment, which in turn increases junctional E-cadherin (Stehbens et al. 2006). Intercellular junctions also control the spatial distribution of MTs. Notably, DSMs are required for reorganization of MTs to cell-cell contacts in differentiating keratinocytes through interactions with the centrosomal protein ninein, whose redistribution to cellcell contacts along with MTs requires desmoplakin (Lechler and Fuchs 2007). Collectively, these data paint a picture of cooperative interactions between cadherin-based junctions and MTs in junction assembly and regulation of MT dynamics and organization.

\section{Role of Rabs and the Exocyst}

Cadherin trafficking and junction assembly is tailored through small GTPases called Rabs which recruit specific effectors in the secretion process (Caviston and Holzbaur 2006). E-cadherin has been reported to associate with an intermediate Rab11-positive recycling compartment in MDCK cells (Lock and Stow 2005). Further, Rab11 is associated with the exocyst, a multisubunit complex responsible for correct targeting of proteins to the plasma membrane. Loss of function of the exocyst components sec 5, 6, and 15 results in accumulation of Drosophila E-cadherin in a Rab11 compartment, inhibiting its delivery to the membrane (Langevin et al. 2005). Interfering with the tight junction scaffold protein associated with Lin seven 1 (PALS1) results in mislocalization of the exocyst and impairs E-cadherin delivery to the plasma membrane (Wang et al. 2007), and coordination between these junctions is facilitated by the balance of activities of Rab13 and Rab8 and their associated proteins (Yamamura et al. 2008).

How desmosomal and classic cadherins are coordinated during their egress out to the cell surface is not well understood. Based on the existence of "mixed" junctions that occur naturally or because of genetic interference, it seems plausible that cotrafficking of classic and desmosomal cadherins may be coupled with mechanisms to remodel or segregate components into distinct junctions in epithelial tissues (Bornslaeger et al. 1995; Ruiz et al. 1996; Borrmann et al. 2006). Temporal analysis of vesicular trafficking following a calcium switch suggests that $60-\mathrm{nm}$ vesicles containing mostly Dsc2 are first observed to transport to the entire cell surface (Burdett 1998), consistent with the possibility that desmocollins serve as initiators of junction assembly in vitro (Hanakawa et al. 2000) and during embryogenesis. Larger vesicles containing desmoglein and E-cadherin were later observed to target basolaterally where they presumably associate with desmocollins and stabilize at sites of junction assembly (Wollner et al. 1992; Burdett 1998). Electron microscope pulse-chase 
K.J. Green et al.

experiments demonstrated that in keratinocytes, desmogleins first form small clusters on the surface lacking IF attachment, and later found associated with IF-attached desmosomal plaques (Sato et al. 2000). Collectively, these data suggest both a temporal and spatial staging of cadherin targeting and incorporation into junctions.

\section{Establishing Functional Adhesion}

Two models have been proposed to explain how intercellular adhesion is established once cadherins have arrived at the plasma membrane. The first depends on the initial formation of lateral or "cis" cadherin dimers, which then come together on adjacent cells to interact in trans, followed by a zippering of the adhesive interface (Shapiro et al. 1995; Pokutta and Weis 2007). The second suggests that cadherin monomers interact in trans to form a "strand dimer" (Boggon et al. 2002), an arrangement supported by site-specific cross-linking experiments (Troyanovsky et al. 2003) and visualized by tomographic analysis of DSMs (He et al. 2003). Additional support for this idea comes from recent single-molecule structural (fluorescence resonance energy transfer) and functional (atomic force microscopy) assays that identified trans but not cis interactions (Zhang et al. 2009).

In contrast to classic cadherins, robust desmosomal cadherin-mediated adhesion requires the presence of both desmogleins and desmocollins in the correct ratio (Amagai et al. 1994; Chidgey et al. 1996; Kowalczyk et al. 1996; Marcozzi et al. 1998; Tselepis et al. 1998; Getsios et al. 2004a). Biochemical and atomic force microscopy (AFM) suggest that desmosomal cadherins are capable of interacting in both homophilic and heterophilic configurations (Syed et al. 2002; Waschke et al. 2005; Heupel et al. 2008) and desmocollin and desmoglein from neighboring cells can be coprecipitated (Chitaev and Troyanovsky 1997). However, the organization of desmosomal cadherins in situ is still unknown.

It has been suggested that weak trans interactions (Chen et al. 2005) are subsequently strengthened by lateral cadherin clustering and cytoskeleton attachment (Gumbiner 1996; Kusumi et al. 1999). But the possible existence of higher affinity interactions is supported by the isolation of cadherin dimers from cells (Chitaev and Troyanovsky 1997) and the observation that cadherin mutants lacking cateninbinding sites can support cell-cell adhesion (Ozawa and Kemler 1998). The discrepancy between in vivo and in vitro data could arise from incomplete unfolding of the cadherin EC1 domain in vitro that makes strand dimer formation impossible (Troyanovsky et al. 2007). The observed range of mechanical strengths between trans-bonded E-cadherin pairs is also consistent with the possibility that longer lived associations can exist (Perret et al. 2004).

Assembly of the Junctional Plaque: Actin Remodeling and Desmosome Assembly are Linked

Although one can debate the existence of weak versus strong cadherin-cadherin dimers, the cortical actin cytoskeleton and myosin II activity are clearly required for adhesion strengthening, junctional plaque assembly and maintenance (Chu et al. 2004; Mege et al. 2006; Miyake et al. 2006). Classic cadherin ligation triggers rearrangements and polymerization of cortical actin that drive formation of the AJ plaque (Yonemura et al. 1995; Perez-Moreno and Fuchs 2006; Pokutta et al. 2008). During this time, the process of DSM assembly and establishment of IF attachments is set into motion, the latter stages occurring in an actin-dependent manner (Figs. 3 and 4) (Green et al. 1987; Godsel et al. 2005). A functional link between actin rearrangements and desmosome assembly may help explain why interfering with classic cadherins or $\alpha$-catenin suppresses desmosome formation (Gumbiner et al. 1988; Watabe et al. 1994; Amagai et al. 1995; Taniguchi et al. 2005). Here, we will discuss actin remodeling pathways triggered by cadherin-dependent cell contact and then explore how these events may couple with downstream assembly of DSMs. 


\author{
Classic Cadherins Trigger Rho \\ GTPase-Dependent Actin Polymerization \\ and Contractile Signaling
}

Cell contact occurs through the extension of lamellopodia driven by the polymerization of branched actin filaments at the leading edge of simple polarized epithelial cells (Drees et al. 2005), or filopodial projections driven by polymerization of linear actin bundles, as has been described in primary keratinocytes and developing Drosophila/Caenorhabditis elegans during tissue morphogenesis (Raich et al. 1999; Vasioukhin et al. 2000; Bloor and Kiehart 2002). The extent to which cells use one or both of these actin-dependent processes to drive the initial stages of adhesion in specific cell types is not known. It seems likely that a combination of mechanisms and actin modulators tailor remodeling of the cell cortex to contextual and cell type differences (Gates and Peifer 2005).

In the contacting lamellopodia of MDCK cells, a highly mobile fraction of E-cadherin (Adams et al. 1998) converts into immobile puncta and ultimately into larger plaques whose formation and stability requires an intact actin cytoskeleton (Adams et al. 1996). Actin rearrangements occur in concert with alterations in Rac1, Cdc42, and RhoA signaling triggered by nectin and cadherin-mediated contacts (Noren et al. 2001; Irie et al. 2004). Rac-dependent recruitment of arp $2 / 3$ (Kovacs et al. 2002), which promotes polymerization of branched actin filaments, collaborates with actin binding proteins such as cortactin, to facilitate expansion of the contact zone (Helwani et al. 2004). Actin remodeling progresses through the local accumulation and dimerization of $\alpha$-catenin near contact sites. In its dimerized form, $\alpha$-catenin inhibits Arp2/3, converting actin from branched to linear, bundled arrays typical of maturing AJs (Yamada et al. 2005).

Rho activity facilitates contact expansion by activating actomyosin contractility in the flanking regions of the junctional contact zone (Yamada and Nelson 2007). Rho also regulates formins, actin-associated proteins that mediate polymerization of linear bundles. The Rho effector Dia is required for junction stability and attenuation of protrusive activity in vertebrates and Drosophila (Sahai and Marshall 2002; Homem and Peifer 2008), depending on myosin II activity for reinforcement of cell-cell junctions (Carramusa et al. 2007). Formins are also recruited by $\alpha$-catenin to E-cadherin-tipped filopodia that project into neighboring keratinocytes to draw them together and initiate AJ assembly (Kobielak et al. 2004). Rho activity can also destabilize junctions through alternate pathways (Sahai and Marshall 2002; Zandy et al. 2007; Fang et al. 2008). The ability of the cadherinassociated protein p120catenin to inhibit Rho through p190RhoGAP may ensure that Rho activity is properly titrated at cell-cell junctions (Wildenberg et al. 2006). The continued activities of Rho and its downstream effector ROCK help to transform keratinocyte sheets to stratifying tissues (Vaezi et al. 2002) and increase the height of polarized epithelial cells (Zhang et al. 2005).

\section{AJ Maturation and Assembly of the Desmosomal Plaque}

Shortly after calcium-induced cell contact in keratinocytes, electron-dense desmosome precursors associated with keratin IF align along perpendicular actin bundles that appear to emanate from newly formed AJ plaques (Green et al. 1987; Godsel et al. 2005). These precursors eventually disappear from the cytoplasm as DSMs mature (Jones and Goldman 1985; Pasdar and Nelson 1988), frequently alternating with AJs along contacting cell borders (Green et al. 1987) (Fig. 3). Live cell imaging of desmoplakin-GFP suggests that these precursors represent part of a three phase process that occurs in response to cell-cell contact in cultured keratinocytes at the leading edge of a wound. Desmosomal plaque assembly begins with the rapid accumulation of desmoplakin at contacting borders followed by a second phase (within $\sim 20-30 \mathrm{~min}$ of cell contact) in which fluorescent bright nonmembrane bound desmoplakin-containing particles form 
K.J. Green et al.

in the cortical region of the cell. The subsequent translocation of particles to nascent junctions to reinforce the plaque, is coordinated with actin rearrangements and dependent on myosin II activity (Godsel et al. 2005 and unpublished results). Once formed, desmosomes continue to exhibit dynamic fusion events as well as internalization and retrograde transport (Windoffer et al. 2002).

How is the desmoplakin-IF system coupled to AJ assembly and the actin-based machinery? Although plakoglobin has been the focus of early studies as important for junctional cross talk (Lewis et al. 1997), inducible expression of the p120-related protein PKP1 has also been reported to initiate DSM assembly in a classic cadherin-dependent fashion (Wahl 2005). In addition to interacting with desmoplakin and IF, PKPs can associate with actin and cause p120-like rearrangements of the actin cytoskeleton (Hatzfeld et al. 2000) (Chen, Bass-Zubek, and Green, unpublished). PKP2 deficiency also results in major alterations in the actin cytoskeleton and rhoA signaling, likely interfering with AJ-dependent actin remodeling driving DSM assembly (BassZubek, Godsel and Green, unpublished). Thus, PKPs may provide a link between the desmoplakin-IF network and an actindependent phase of desmosome assembly.

Loss of PKP2 also results in retention of desmoplakin on IF, preventing its incorporation into DSMs. This "beads on a string" appearance of desmoplakin is reminiscent of the distribution of desmoplakin in PKC $\alpha$ knockdown cells (Bass-Zubek et al. 2008) and a phosphorylation deficient desmoplakin mutant (S2849G) that exhibits delayed outward trafficking (Godsel et al. 2005) because of its higher affinity for, and aberrant retention on, IF (Stappenbeck et al. 1994; Meng et al. 1997; Fontao et al. 2003). Our data suggest a model whereby PKP2 scaffolding of PKC $\alpha$ promotes desmoplakin phosphorylation and assembly competence (Bass-Zubek et al. 2008). Consistent with this, PKC restores DSM assembly in $\alpha$-catenin-null colon carcinoma cells and can promote DSM assembly even in reduced calcium (Sheu et al. 1989; Hengel et al. 1997). PKPs also collaborate with plakoglobin to mediate desmosomal cadherin clustering into ultrastructurally identifiable plaques (Bornslaeger et al. 2001; Koeser et al. 2003).

Like AJs, DSMs undergo a period of maturation, ultimately attaining a hyper-adhesive state which can be reversed by the calciumdependent kinase PKC $\alpha$ (Watt et al. 1984; Wallis et al. 2000; Garrod et al. 2005; Kimura et al. 2006). The fact that PKC $\alpha$ also promotes desmosome assembly supports the idea that this kinase is important for maintaining a dynamic state, which would allow rapid desmosome remodeling in response to environmental cues. Desmosomes are also defective in patients with Darier's disease who have impaired calcium homeostasis because of mutations in the sarco(endo)plasmic reticulum $\mathrm{Ca}^{2+}$-ATPase (SERCA) isoform 2 pump (Sakuntabhai et al. 1999; Dhitavat et al. 2003). Although these abnormalities were suggested to arise from improper folding of desmoplakin, it also seems possible that alterations in calcium-dependent kinase activity could contribute to the observed defects.

Achieving maximum mechanical integrity of epithelial cell sheets requires proper attachments of junctions to both IF and cortical actin, as intercellular adhesion is synergistically strengthened by the presence of IF and actin attachments (Huen et al. 2002). Further, AJs are unable to mature properly in cells lacking desmoplakin and normal IF attachments suggesting bi-directional regulation between AJs and DSMs (Vasioukhin et al. 2001b).

\section{JUNCTION HOMEOSTASIS: ROLE OF ENDOCYTOSIS}

AJs and DSMs can be modified posttranslationally by physiological stimuli resulting in changes in phosphorylation state and proteolytic processing (Gumbiner 2005; Green and Simpson 2007). These processes have traditionally been proposed to alter interactions with the cytoskeleton, thus weakening adhesive strength. However, modification of the cadherins and their associated proteins can also regulate endocytic internalization and recycling (Bryant and 
Stow 2004; Ivanov et al. 2005; Yap et al. 2007; Delva and Kowalczyk 2009). Derailed endocytosis of cadherins may contribute to tumor progression (Mosesson et al. 2008) and blister formation in the autoimmune disease pemphigus (Kottke et al. 2006).

Like other receptors, cadherins can be constitutively endocytosed by a clathrin-dependent pathway (Le et al. 1999; Palacios et al. 2002; Xiao et al. 2005), possibly via binding of the adaptor complex AP2 to the dileucine motif in the juxtamembrane region (Miyashita and Ozawa 2007). This motif may be exposed on dissociation of $\mathrm{p} 120$, consistent with earlier work demonstrating a role for p120 in E-cadherin stability (Davis et al. 2003; Xiao et al. 2003). However, other determinants must be responsible for clathrin-dependent endocytosis of VE-cadherin, because even though it is similarly regulated by p120 (Xiao et al. 2005), it does not possess such a motif. Further, $\mathrm{N}$-cadherin intracellular regions lacking the dileucine motif facilitate endocytosis (Tai et al. 2007). Basolateral targeting of E-cadherin may also be regulated by the dileucine motif (Lock and Stow 2005), and assembly and recycling facilitated by the adapter mu1B subunit through a variant of PIPK $\gamma$ (Ling et al. 2007).

Growth factors such as TGF $\beta$ (Janda et al. 2006), EGF (Lu et al. 2003; Hirao et al. 2006; Bryant et al. 2007), HGF (Palacios et al. 2001), and, FGF (Bryant et al. 2005) can promote internalization and loss of junctions. Further, cadherin molecules can physically complex with growth factor receptors including EGF receptor, ErbB-1 (Dumstrei et al. 2002; Fedor-Chaiken et al. 2003) HGF receptor, c-Met (Davies et al. 2001) and FGFR (Suyama et al. 2002). These associations can either promote internalization or stabilize cell surface retention, impacting both junction integrity and growth factor-dependent signaling.

Small molecule inhibitors of EGFR/ErB2 have been shown to block internalization of E-cadherin and desmoglein 2 in tumor cells, resulting in increased adhesive strength even under conditions of reduced calcium, highlighting the therapeutic value of EGFR inhibitors for patients with cancers that overexpress EGFR
(Lorch et al. 2004; Klessner et al. 2009). The ADAM family of sheddases cooperates with EGFR in increasing the internalized pool of desmoglein 2, thus reducing adhesive strength (Klessner et al. 2009). Different endocytic pathways have been suggested to mediate growth factor-regulated endocytosis, including rac-dependent macropinocytosis (Akhtar and Hotchin 2001; Bryant et al. 2007) and caveolindependent endocytosis (Lu et al. 2003).

Growth factor stimulation has also been linked to activation of nonreceptor tyrosine kinases such as Src. Src-dependent phosphorylation of two tyrosines of E-cadherin (Y755 and Y756) produces a binding site for E3 ubiquitin-ligase Hakai, and ubiquitination of the E-cadherin-catenin complex facilitates clathrin-dependent internalization (Fujita et al. 2002) and targeting for lysosomal degradation (Palacios et al. 2005). This pathway likely explains cadherin internalization and dissolution of AJs shown to accompany the activation of ts-v-Src in MDCK cells (Warren and Nelson 1987; Palovuori et al. 2003) or reduced extracellular calcium via activation of Cdc42 (Shen et al. 2008).

Desmosomal cadherin internalization is a contributing factor in the autoimmune disease pemphigus (Kottke et al. 2006). Dsg3 is degraded in response to PV autoantibody binding resulting in Dsg3-depleted DSMs (Aoyama and Kitajima 1999), shown to be because of rapid clathrin- and dynaminindependent internalization of a soluble pool of PV-IgG-bound Dsg3 (Calkins et al. 2006; Delva et al. 2008). PV antibodies may impair assembly of new DSMs by targeting internalization of newly synthesized Dsg3 (Sato et al. 2000; Mao et al. 2009). Although it has been reported that plakoglobin, but not desmoplakin, remains associated with the cadherin (Calkins et al. 2006), others suggest that plakoglobin dissociates from phosphorylated Dsg3 after which it is degraded, depleting a nuclear pool required for attenuating c-myc transcription (Muller et al. 2006). PV induces alterations in both IF attachment (Caldelari et al. 2001; Calkins et al. 2006) and cortical actin (Waschke et al. 2006). The latter has been 


\section{K.J. Green et al.}

linked with a reduction in Rho A activity, suggesting another link between pathways regulating AJs and DSMs (Waschke et al. 2006).

Endocytosis can be envisioned to target two pools of cadherin molecules_engaged or unengaged in adhesion. In isolated epithelial MCF-7 cells, a pool of free cadherin is subjected to macropinocytosis (Paterson et al. 2003; Bryant et al. 2007) and clathrin-dependent endocytosis was suggested to target extrajunctional cadherin (Izumi et al. 2004; Hoshino et al. 2005). However, it is also plausible that cadherins are internalized directly from the intrajunctional region, forcefully breaking apart cadherin adhesive bonds. This would be consistent with the observed association of endocytic vesicles with AJs and supported by the protective effect of endocytosis inhibitors, which lead to the rapid expansion of the junctional interface (Troyanovsky et al. 2006). Thus, cadherin endocytosis may be essential to counterbalance a continuous assembly of cadherin dimers in AJs. Supporting this idea, defects in endocytosis induced by the lack of dynamin or proteins involved in Arp2/ 3-dependent actin polymerization prevented completion of endocytosis in Drosophilia epithelial cells (Georgiou et al. 2008; Leibfried et al. 2008). Together the data suggest that different endocytic routes collaborate to regulate the assembly state of adhering junctions in normal tissues and pathogenic states.

\section{JUNCTION ASSEMBLY IN COMPLEX TISSUES: CHALLENGES FOR THE FUTURE}

Onto these basic modes of junction assembly and remodeling are overlaid additional complexities in the case of tissues such as the epidermis. This stratified squamous epithelium does not exhibit the typical apico-basolateral polarity found in simple epithelial cells. Yet, junctional components are integrated into specialized membrane complexes in a polarized fashion as basal layer keratinocytes stratify and differentiate (Green and Simpson 2007; Niessen 2007; Fuchs 2008). For example, adherens junction-enriched basal keratinocytes are accompanied by increasing numbers of DSMs, which change in molecular composition in the spinous layers and granular layers (Fig. 5 and Fig. 3 of Delva et al. 2009). Although many

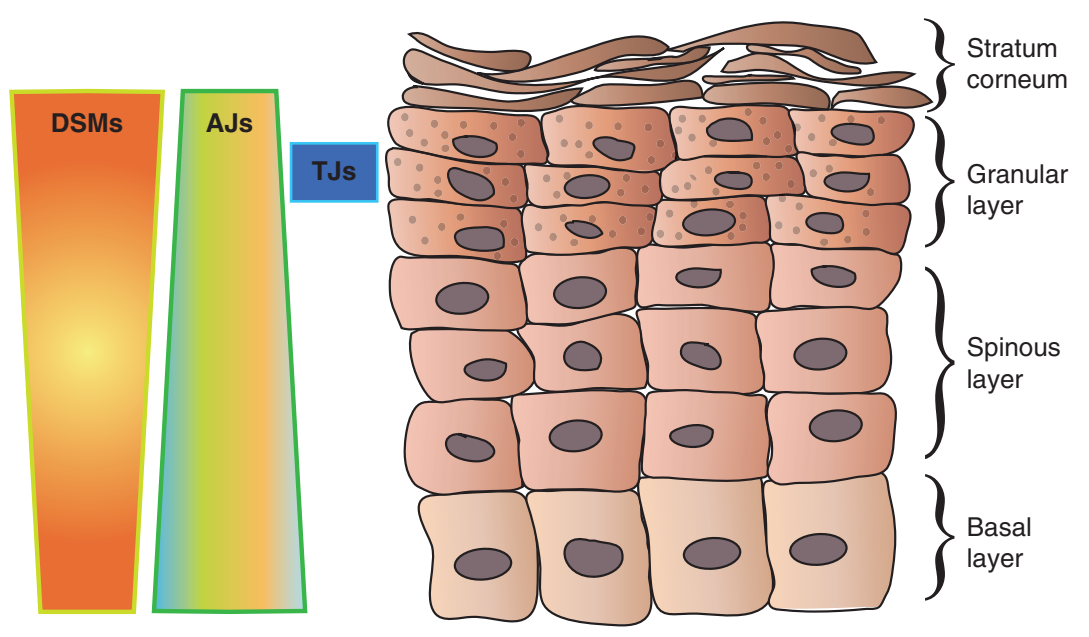

Figure 5. Organization of intercellular junctions in the epidermis. Desmosomes and AJs are found throughout the epidermis but AJs enriched in E- and P-cadherin are found in the basal layers whereas the number and surface area occupied by DSMs increases during differentiation, during which time P-cadherin is lost. See Kowalczyk and colleagues (Delva et al. 2009, Fig. 3) for the expression patterns of DSM components during differentiation in epidermis. The TJ barrier is in the granular layer of the epidermis, with structurally definable junctions restricted to the second cell layer. 
tight junction components (e.g., claudin-1, occludin, and ZO-1) are expressed throughout the epidermis, a tight junction barrier is sealed only in granular cells before these eventually give rise to a cornified dead cell layer (Furuse et al. 2002). Thus, junction assembly in the epidermis is coordinated throughout multiple cell layers instead of within distinct basolateral membrane domains of a simple epithelial cell.

As in the case of compacting embryos, keratinocytes devoid of classical cadherins (E- and P-cadherin) fail to elaborate DSMs and tight junctions in vitro (Tinkle et al. 2008; Michels et al. 2009). Although depletion of classical cadherins interferes with epidermal cohesion and the tight junction barrier in vivo, desmosomes still form in epidermis lacking classical cadherins or alpha-catenin (Vasioukhin et al. 2001a; Tunggal et al. 2005; Tinkle et al. 2008). $\alpha$-catenin also plays an important role in orienting the mitotic spindle in the basal layer for asymmetric cell divisions that promote stratification into the differentiated layers (Lechler and Fuchs 2005). The lack of desmoplakin has little influence on the place of cell division in basal keratinocytes, but this IF binding protein regulates MTorganization in the suprabasal epidermis via interactions with ninein (Lechler and Fuchs 2007). These studies emphasize that elaboration of AJs and DSMs into a stratified epithelium not only holds the tissue together but also provides positional cues for targeting cytoskeletal, trafficking, and endocytic machineries.

How junction assembly and remodeling occurs on the molecular level in vertebrate tissues in vivo is a challenge for future study. During stratification, DSMs with different compositions reflecting differentiation-dependent expression patterns must either be made de novo or remodeled or both (North et al. 1996). In part this remodeling may be driven by transcriptional programs, such as that regulated by grainyhead transcription factors that drive expression of desmoglein 1 in differentiated layers of the epidermis (Wilanowski et al. 2008). Once expressed, whether newly synthesized cadherins are immediately incorporated into junctions or require additional regulatory cues or post-translational modifications, similar to those that occur during embryogenesis, is unknown. We also do not yet know whether, once assembly competent, molecules are inserted into pre-existing junctions or used to create new junctions. In the future, studies at the molecular level that address fundamental properties of junction dynamics, coupled with genetic analysis of in vivo models, should begin to reveal the complexity of mechanisms used in vivo.

\section{ACKNOWLEDGMENTS}

The authors would like to acknowledge Andrew Kowalczyk for helpful comments and discussion. Work in the authors' labs is supported by NIH R01's AR43380, AR41836, CA122151 (K.G.), a Dermatology Career Development Award and Zell Foundation Awards (S.G.), and R01 AR44016 (S.T.).

\section{REFERENCES}

Abe K, Takeichi M. 2008. EPLIN mediates linkage of the cadherin catenin complex to F-actin and stabilizes the circumferential actin belt. Proc Natl Acad Sci 105: $13-19$

Abedin M, King N. 2008. The premetazoan ancestry of cadherins. Science 319: 946-948.

Adams CL, Nelson WJ, Smith SJ. 1996. Quantitative analysis of cadherin-catenin-actin reorganization during development of cell-cell adhesion. J Cell Biol 135: 1899-1911.

Adams CL, Chen Y-T, Smith SJ, Nelson WJ. 1998. Mechanisms of epithelial cell-cell adhesion and cell compaction revealed by high-resolution tracking of E-cadherin-green fluorescent protein. J Cell Biol 142: 1105-1119.

Akhtar N, Hotchin NA. 2001. RAC1 regulates adherens junctions through endocytosis of E-cadherin. Mol Biol Cell 12: 847-862.

Amagai M, Karpati S, Klaus-Kovtun V, Udey MC, Stanley JR. 1994. The extracellular domain of pemphigus vulgaris antigen (desmoglein 3) mediates weak homophilic adhesion. J Invest Derm 102: 402-408.

Amagai M, Fujimori T, Masunaga T, Shimizu H, Nishikawa T, Shimizu N, Takeichi M, Hashimoto T. 1995. Delayed assembly of desmosomes in keratinocytes with disrupted classic-cadherin-mediated cell adhesion by a dominant negative mutant. J Invest Derm 104: 27-32.

Andl CD, Stanley JR. 2001. Central role of the plakoglobinbinding domain for desmoglein 3 incorporation into desmosomes. J Invest Dermatol 117: 1068-1074.

Aoyama Y, Kitajima Y. 1999. Pemphigus vulgaris-IgG causes a rapid depletion of desmoglein 3 (Dsg3) from the Triton 


\section{K.J. Green et al.}

X-100 soluble pools, leading to the formation of Dsg3depleted desmosomes in a human squamous carcinoma cell line, DJM-1 cells. J Invest Dermatol 112: 67-71.

Barcroft LC, Hay-Schmidt A, Caveney A, Gilfoyle E, Overstrom EW, Hyttel P, Watson AJ. 1998. Trophectoderm differentiation in the bovine embryo: Characterization of a polarized epithelium. J Reprod Fertil 114: 327-339.

Bass-Zubek AE, Hobbs RP, Amargo EV, Garcia NJ, Hsieh SN, Chen X, Wahl JK 3rd, Denning MF, Green KJ. 2008. Plakophilin 2: A critical scaffold for PKC $\alpha$ that regulates intercellular junction assembly. J Cell Biol 181: 605-613.

Bloor JW, Kiehart DP. 2002. Drosophila RhoA regulates the cytoskeleton and cell-cell adhesion in the developing epidermis. Development 129: 3173-3183.

Boggon TJ, Murray J, Chappuis-Flament S, Wong E, Gumbiner BM, Shapiro L. 2002. C-cadherin ectodomain structure and implications for cell adhesion mechanisms. Science 296: 1308-1313.

Bornslaeger EA, Corcoran CM, Stappenbeck TS, Green KJ. 1995. Disruption of desmosome assembly and linkage to keratin intermediate filament bundles by an amino terminal domain of the desmosomal plaque protein desmoplakin. Mol Biol Cell 6: p341a.

Bornslaeger E, Godsel L, Corcoran C, Park J, Hatzfeld M, Kowalczyk A, Green K. 2001. Plakophilin 1 interferes with plakoglobin binding to desmoplakin, yet together with plakoglobin promotes clustering of desmosomal plaque complexes at cell-cell borders. J Cell Sci 114: 727-738.

Borrmann CM, Grund C, Kuhn C, Hofmann I, Pieperhoff S, Franke WW. 2006. The area composita of adhering junctions connecting heart muscle cells of vertebrates. II. Colocalizations of desmosomal and fascia adhaerens molecules in the intercalated disk. Eur J Cell Biol 85: 469-485.

Brembeck FH, Rosario M, Birchmeier W. 2006. Balancing cell adhesion and Wnt signaling, the key role of $\beta$-catenin. Curr Opin Genet Dev 16: 51-59.

Bryant DM, Stow JL. 2004. The ins and outs of E-cadherin trafficking. Trends Cell Biol 14: 427-434.

Bryant DM, Wylie FG, Stow JL. 2005. Regulation of endocytosis, nuclear translocation, signaling of fibroblast growth factor receptor 1 by E-cadherin. Mol Biol Cell 16: 14-23.

Bryant DM, Kerr MC, Hammond LA, Joseph SR, Mostov KE, Teasdale RD, Stow JL. 2007. EGF induces macropinocytosis and SNX1-modulated recycling of E-cadherin. J Cell Sci 120: $1818-1828$.

Burdett IDJ. 1998. Aspects of the structure and assembly of desmosomes. Micron 29: 309-328.

Caldelari R, de Bruin A, Baumann D, Suter MM, Bierkamp C, Balmer V, Muller E. 2001. A central role for the armadillo protein plakoglobin in the autoimmune disease pemphigus vulgaris. J Cell Biol 153: 823-834.

Calkins CC, Setzer SV, Jennings JM, Summers S, Tsunoda K, Amagai M, Kowalczyk AP. 2006. Desmoglein endocytosis and desmosome disassembly are coordinated responses to pemphigus autoantibodies. $J$ Biol Chem 281: 7623-7634.

Carramusa L, Ballestrem C, Zilberman Y, Bershadsky AD. 2007. Mammalian diaphanous-related formin Dial controls the organization of E-cadherin-mediated cellcell junctions. J Cell Sci 120: 3870-3882.

Caviston JP, Holzbaur EL. 2006. Microtubule motors at the intersection of trafficking and transport. Trends Cell Biol 16: $530-537$.

Chen Y-T, Stewart DB, Nelson WJ. 1999. Coupling assembly of the E-cadherin/b-catenin complex to efficient endoplasmic reticulum exit and basal-lateral membrane targeting of E-cadherin in polarized MDCK cells. $J$ Cell Biol 144: 687-699.

Chen X, Kojima S, Borisy GG, Green KJ. 2003. 120 catenin associates with kinesin and facilitates the transport of cadherin-catenin complexes to intercellular junctions. J Cell Biol 163: 547-557.

Chen CP, Posy S, Ben-Shaul A, Shapiro L, Honig BH. 2005. Specificity of cell-cell adhesion by classical cadherins: Critical role for low-affinity dimerization through $\beta$-strand swapping. Proc Natl Acad Sci 102: 8531-8536.

Cheng X, Koch PJ. 2004. In vivo function of desmosomes. J Dermatol 31: 171-187.

Chidgey MAJ, Clarke JP, Garrod DR. 1996. Expression of full-length desmosomal glycoproteins (desmocollins) is not sufficient to confer strong adhesion on transfected L929 cells. J Invest Derm 106: 689-695.

Chitaev NA, Troyanovsky SM. 1997. Direct $\mathrm{Ca}^{+}$. dependent heterophilic interaction between desmosomal cadherins, desmoglein and desmocollin, contributes to cell-cell adhesion. J Cell Biol 138: 193-201.

Chu YS, Thomas WA, Eder O, Pincet F, Perez E, Thiery JP, Dufour S. 2004. Force measurements in E-cadherinmediated cell doublets reveal rapid adhesion strengthened by actin cytoskeleton remodeling through Rac and Cdc42. J Cell Biol 167: 1183-1194.

Clayton L, Hall A, Johnson MH. 1999. A role for Rho-like GTPases in the polarisation of mouse eight-cell blastomeres. Dev Biol 205: 322-331.

Collins JE, Lorimer JE, Garrod DR, Pidsley SC, Buxton RS, Fleming TP. 1995. Regulation of desmocollin transcription in mouse preimplantation embryos. Development 121: $743-753$.

Davies G, Jiang WG, Mason MD. 2001. HGF/SF modifies the interaction between its receptor c-Met, the E-cadherin/catenin complex in prostate cancer cells. Int J Mol Med 7: 385-388.

Davis MA, Ireton RC, Reynolds AB. 2003. A core function for 120-catenin in cadherin turnover. J Cell Biol 163 525-534.

De Vries WN, Evsikov AV, Haac BE, Fancher KS, Holbrook AE, Kemler R, Solter D, Knowles BB. 2004. Maternal $\beta$-catenin and E-cadherin in mouse development. Development 131: 4435-4445.

Delva E, Kowalczyk AP. 2009. Regulation of cadherin trafficking. Traffic 10: 259-267.

Delva E, Jennings JM, Calkins CC, Kottke MD, Faundez V, Kowalczyk AP. 2008. Pemphigus vulgaris IgG-induced desmoglein- 3 endocytosis and desmosomal disassembly are mediated by a clathrin- and dynamin-independent mechanism. J Biol Chem 283: 18303-18313.

Delva E, Tucker DK, Kowalczyk AP. 2009. The desmosome. Cold Spring Harb Perspect Biol 1: 002543. 
Den Z, Cheng X, Merched-Sauvage M, Koch PJ. 2006. Desmocollin 3 is required for pre-implantation development of the mouse embryo. J Cell Sci 119: 482-489.

Dhitavat J, Cobbold C, Leslie N, Burge S, Hovnanian A. 2003. Impaired trafficking of the desmoplakins in cultured Darier's disease keratinocytes. J Invest Dermatol 121: 1349-1355.

Drees F, Pokutta S, Yamada S, Nelson WJ, Weis WI. 2005. $\alpha$-catenin is a molecular switch that binds E-cadherin$\beta$-catenin and regulates actin-filament assembly. Cell 123: 903-915.

Dumstrei K, Wang F, Shy D, Tepass U, Hartenstein V. 2002. Interaction between EGFR signaling and DE-cadherin during nervous system morphogenesis. Development 129: 3983-3994.

Eckert JJ, Fleming TP. 2008. Tight junction biogenesis during early development. Biochim Biophys Acta 1778: 717-728.

Fang WB, Ireton RC, Zhuang G, Takahashi T, Reynolds A, Chen J. 2008. Overexpression of EPHA2 receptor destabilizes adherens junctions via a RhoA-dependent mechanism. J Cell Sci 121: 358-368.

Fedor-Chaiken M, Hein PW, Stewart JC, Brackenbury R, Kinch MS. 2003. E-cadherin binding modulates EGF receptor activation. Cell Commun Adhes 10: 105-118.

Fleming TP, Garrod DR, Elsmore AJ. 1991. Desmosome biogenesis in the mouse preimplantation embryo. Development 112: 527-539.

Fleming TP, Javed Q, Collins J, Hay M. 1993. Biogenesis of structural intercellular junctions during cleavage in the mouse embryo. J Cell Sci Suppl 17: 119-125.

Fontao L, Favre B, Riou S, Geerts D, Jaunin F, Saurat JH, Green KJ, Sonnenberg A, Borradori L. 2003. Interaction of the bullous pemphigoid antigen 1 (BP230) and desmoplakin with intermediate filaments is mediated by distinct sequences within their $\mathrm{COOH}$ terminus. Mol Biol Cell 14: 1978-1992.

Fuchs E. 2008. Skin stem cells: Rising to the surface. J Cell Biol 180: 273-284.

Fujita Y, Krause G, Scheffner M, Zechner D, Leddy HE, Behrens J, Sommer T, Birchmeier W. 2002. Hakai, a c-Cbl-like protein, ubiquitinates and induces endocytosis of the E-cadherin complex. Nat Cell Biol 4: 222-231.

Furukawa C, Daigo Y, Ishikawa N, Kato T, Ito T, Tsuchiya E, Sone S, Nakamura Y. 2005. Plakophilin 3 oncogene as prognostic marker and therapeutic target for lung cancer. Cancer Res 65: 7102-7110.

Furuse $M$, Hata $M$, Furuse K, Yoshida Y, Haratake A, Sugitani Y, Noda T, Kubo A, Tsukita S. 2002. Claudin-based tight junctions are crucial for the mammalian epidermal barrier: A lesson from claudin-1deficient mice. J Cell Biol 156: 1099-1111.

Garrod DR, Berika MY, Bardsley WF, Holmes D, Tabernero L. 2005. Hyper-adhesion in desmosomes: Its regulation in wound healing and possible relationship to cadherin crystal structure. J Cell Sci 118: 5743-5754.

Garrod D, Chidgey M. 2008. Desmosome structure, composition and function. Biochim Biophys Acta 1778: 572-587.

Gates J, Peifer M. 2005. Can 1000 reviews be wrong? Actin, $\alpha$-Catenin, adherens junctions. Cell 123: 769-772.
Georgiou M, Marinari E, Burden J, Baum B. 2008. Cdc42, Par6, aPKC regulate Arp2/3-mediated endocytosis to control local adherens junction stability. Curr Biol 18: $1631-1638$.

Getsios S, Amargo EV, Dusek RL, Ishii K, Sheu L, Godsel LM, Green KJ. 2004a. Coordinated expression of desmoglein 1 and desmocollin 1 regulates intercellular adhesion. Differentiation 72: 419-433.

Getsios S, Huen AC, Green KJ. 2004b. Working out the strength and flexibility of desmosomes. Nat Rev Mol Cell Biol 5: 271-281.

Godsel LM, Hsieh SN, Amargo EV, Bass AE, PascoeMcGillicuddy LT, Huen AC, Thorne ME, Gaudry CA, Park JK, Myung K, et al. 2005. Desmoplakin assembly dynamics in four dimensions: Multiple phases differentially regulated by intermediate filaments and actin. J Cell Biol 171: 1045-1059.

Green KJ, Simpson CL. 2007. Desmosomes: New perspectives on a classic. J Invest Dermatol 127: 2499-2515.

Green KJ, Geiger B, Jones JCR, Talian JC, Goldman RD. 1987. The relationship between intermediate filaments and microfilaments prior to and during the formation of desmosomes and adherens-type junctions in mouse epidermal keratinocytes. J Cell Biol 104: 1389-1402.

Grimson MJ, Coates JC, Reynolds JP, Shipman M, Blanton RL, Harwood AJ. 2000. Adherens junctions and $\beta$-catenin-mediated cell signalling in a non-metazoan organism. Nature 408: 727-731.

Grindstaff KK, Bacallao RL, Nelson WJ. 1998. Apiconuclear organization of microtubules does not specify protein delivery from the trans-Golgi network to different membrane domains in polarized epithelial cells. Mol Biol Cell 9: 685-699.

Gumbiner BM. 1996. Cell adhesion: The molecular basis of tissue architecture and morphogenesis. Cell 84: 345-357.

Gumbiner BM. 2005. Regulation of cadherin-mediated adhesion in morphogenesis. Nat Rev Mol Cell Biol 6: $622-634$.

Gumbiner B, Stevenson B, Grimaldi A. 1988. The role of the cell adhesion molecule uvomorulin in the formation and maintenance of the epithelial junctional complex. J Cell Biol 107: 1575-1587.

Haegel H, Larue L, Ohsugi M, Fedorov L, Herrenknecht K, Kemler R. 1995. Lack of b-catenin affects mouse development at gastrulation. Development 121: 3529-3537.

Hanakawa Y, Amagai M, Shirakata Y, Sayama K, Hashimoto K. 2000. Different effects of dominant negative mutants of desmocollin and desmoglein on the cell-cell adhesion of keratinocytes. J Cell Sci 113: 1803-1811.

Hatzfeld M. 2007. Plakophilins: Multifunctional proteins or just regulators of desmosomal adhesion? Biochim Biophys Acta 1773: 69-77.

Hatzfeld M, Haffner C, Schulze K, Vinzens U. 2000. The function of plakophilin 1 in desmosome assembly and actin filament organization. J Cell Biol 149: 209-222.

He W, Cowin P, Stokes DL. 2003. Untangling desmosomal knots with electron tomography. Science 302: 109-113.

Helwani FM, Kovacs EM, Paterson AD, Verma S, Ali RG, Fanning AS, Weed SA, Yap AS. 2004. Cortactin is 


\section{K.J. Green et al.}

necessary for E-cadherin-mediated contact formation and actin reorganization. J Cell Biol 164: 899-910.

Hengel JV, Gohon L, Bruyneel E, Vermeulen S, Cornelissen M, Mareel M, Roy FV. 1997. Protein kinase C activation upregulates intercellular adhesion of a-catenin-negative human colon cancer cell variants via induction of desmosomes. J Cell Biol 137: 1103-1116.

Heupel WM, Zillikens D, Drenckhahn D, Waschke J. 2008. Pemphigus vulgaris IgG directly inhibit desmoglein 3mediated transinteraction. J Immunol 181: 1825-1834.

Hinck L, Nathke IS, Papkoff J, Nelson WJ. 1994. Dynamics of cadherin/catenin complex formation: Ovel protein interactions and pathways of complex assembly. $J$ Cell Biol 125: 1327-1340.

Hirao T, Nanba D, Tanaka M, Ishiguro H, Kinugasa Y, Doki Y, Yano M, Matsuura N, Monden M, Higashiyama S. 2006. Overexpression of ADAM9 enhances growth factor-mediated recycling of E-cadherin in human colon cancer cell line HT29 cells. Experimental cell research 312: 331-339.

Holthofer B, Windoffer R, Troyanovsky S, Leube RE. 2007. Structure and function of desmosomes. Int Rev Cytol 264: $65-163$.

Homem CC, Peifer M. 2008. Diaphanous regulates myosin and adherens junctions to control cell contractility and protrusive behavior during morphogenesis. Development 135: 1005-1018.

Hoshino T, Sakisaka T, Baba T, Yamada T, Kimura T, Takai Y. 2005. Regulation of E-cadherin endocytosis by nectin through afadin, Rap1, 120ctn. J Biol Chem 280: 24095-24103.

Huber AH, Stewart DB, Laurents DV, Nelson WJ, Weis WI. 2001. The cadherin cytoplasmic domain is unstructured in the absence of $\beta$-catenin. A possible mechanism for regulating cadherin turnover. $J$ Biol Chem 276: 12301-12309.

Huen AC, Park JK, Godsel LM, Chen X, Bannon LJ, Amargo EV, Hudson TY, Mongiu AK, Leigh IM, Kelsell DP, et al. 2002. Intermediate filament-membrane attachments function synergistically with actin-dependent contacts to regulate intercellular adhesive strength. J Cell Biol 159: $1005-1017$.

Hulpiau P, van Roy F. 2009. Molecular evolution of the cadherin superfamily. Int J Biochem Cell Biol 41: 349-369.

Hyenne V, Souilhol C, Cohen-Tannoudji M, Cereghini S, Petit C, Langa F, Maro B, Simmler MC. 2007. Conditional knock-out reveals that zygotic vezatin-null mouse embryos die at implantation. Mech Dev 124: $449-462$.

Irie K, Shimizu K, Sakisaka T, Ikeda W, Takai Y. 2004. Roles and modes of action of nectins in cell-cell adhesion. Semin Cell Dev Biol 15: 643-656.

Ivanov AI, Nusrat A, Parkos CA. 2005. Endocytosis of the apical junctional complex: Mechanisms and possible roles in regulation of epithelial barriers. Bioessays 27: $356-365$.

Izumi G, Sakisaka T, Baba T, Tanaka S, Morimoto K, Takai Y. 2004. Endocytosis of E-cadherin regulated by Rac and Cdc42 small G proteins through IQGAP1 and actin filaments. J Cell Biol 166: 237-248.
Jackson BW, Grund C, Schmid E, Burki K, Franke WW, Illmensee K. 1980. Formation of cytoskeletal elements during mouse embryogenesis. Differentiation 17: 161-179.

Janda E, Nevolo M, Lehmann K, Downward J, Beug H, Grieco M. 2006. Raf plus TGF $\beta$-dependent EMT is initiated by endocytosis and lysosomal degradation of E-cadherin. Oncogene 25: 7117-7130.

Jones JCR, Goldman RD. 1985. Intermediate filaments and the initiation of desmosome assembly. J Cell Biol 101: 506-517.

Kabir N, Yamamura H, Takagishi Y, Inouye M, Oda S, Hidaka H. 1996. Regulation of preimplantation development of mouse embryos: Effects of inhibition of myosin light-chain kinase, a $\mathrm{Ca}^{2+} /$ calmodulin-dependent enzyme. J Exp Zool 274: 101-110.

Kami K, Chidgey M, Dafforn T, Overduin M. 2009. The desmoglein-specific cytoplasmic region is intrinsically disordered in solution and interacts with multiple desmosomal protein partners. J Mol Biol 386: 531-543.

Kan NG, Stemmler MP, Junghans D, Kanzler B, de Vries WN, Dominis M, Kemler R. 2007. Gene replacement reveals a specific role for E-cadherin in the formation of a functional trophectoderm. Development 134: 31-41.

Kidder GM, McLachlin JR. 1985. Timing of transcription and protein synthesis underlying morphogenesis in preimplantation mouse embryos. Dev Biol 112: 265-275.

Kimura TE, Merritt AJ, Garrod DR. 2006. CalciumIndependent Desmosomes of Keratinocytes are HyperAdhesive. J Invest Dermatol.

King N, Westbrook MJ, Young SL, Kuo A, Abedin M, Chapman J, Fairclough S, Hellsten U, Isogai Y, Letunic I, et al. 2008. The genome of the choanoflagellate Monosiga brevicollis and the origin of metazoans. Nature 451: 783-788.

Kizhatil K, Davis JQ, Davis L, Hoffman J, Hogan BL, Bennett V. 2007. Ankyrin-G is a molecular partner of E-cadherin in epithelial cells and early embryos. J Biol Chem 282: 26552-26561.

Klessner JL, Desai BV, Amargo EV, Getsios S, Green KJ. 2009. EGFR and ADAMs cooperate to regulate shedding and endocytic trafficking of the desmosomal cadherin desmoglein 2. Mol Biol Cell 20: 328-337.

Kobielak A, Pasolli HA, Fuchs E. 2004. Mammalian formin-1 participates in adherens junctions and polymerization of linear actin cables. Nat Cell Biol 6: 21-30.

Koeser J, Troyanovsky SM, Grund C, Franke WW. 2003. De novo formation of desmosomes in cultured cells upon transfection of genes encoding specific desmosomal components. Experimental cell research 285: 114-130.

Kottke MD, Delva E, Kowalczyk AP. 2006. The desmosome: Cell science lessons from human diseases. J Cell Sci 119: 797-806.

Kovacs EM, Goodwin M, Ali RG, Paterson AD, Yap AS. 2002. Cadherin-directed actin assembly. E-cadherin physically associates with the arp $2 / 3$ complex to direct actin assembly in nascent adhesive contacts. Curr Biol 12: $379-382$.

Kowalczyk AP, Reynolds AB. 2004. Protecting your tail: Regulation of cadherin degradation by p120-catenin. Curr Opin Cell Biol 16: 522-527. 
Kowalczyk AP, Borgwardt JE, Green KJ. 1996. Analysis of desmosomal cadherin-adhesive function and stoichiometry of desmosomal cadherin-plakoglobin complexes. $J$ Invest Derm 107: 293-300.

Kusumi A, Suzuki K, Koyasako K. 1999. Mobility and cytoskeletal interactions of cell adhesion receptors. Curr Opin Cell Biol 11: 582-590.

Lai-Cheong JE, Arita K, McGrath JA. 2007. Genetic diseases of junctions. J Invest Dermatol 127: 2713-2725.

Langevin J, Morgan MJ, Sibarita JB, Aresta S, Murthy M, Schwarz T, Camonis J, Bellaiche Y. 2005. Drosophila exocyst components Sec5, Sec6, Sec15 regulate DE-Cadherin trafficking from recycling endosomes to the plasma membrane. Dev Cell 9: 355-376.

Larue L, Ohsugi M, Hirchenhain J, Kemler R. 1994. E-cadherin null mutant embryos fail to form a trophectoderm epithelium. Proc Natl Acad Sci 91: 8263-8267.

Le TL, Yap AS, Stow JL. 1999. Recycling of E-cadherin: A potential mechanism for regulating cadherin dynamics. J Cell Biol 146: 219-232.

Lechler T, Fuchs E. 2005. Asymmetric cell divisions promote stratification and differentiation of mammalian skin. Nature 437: 275-280.

Lechler T, Fuchs E. 2007. Desmoplakin: An unexpected regulator of microtubule organization in the epidermis. J Cell Biol 176: 147-154.

Leibfried A, Fricke R, Morgan MJ, Bogdan S, Bellaiche Y. 2008. Drosophila Cip4 and WASp define a branch of the Cdc42-Par6-aPKC pathway regulating E-cadherin endocytosis. Curr Biol 18: 1639-1648.

Lewis JE, Wahl JK 3rd, Sass KM, Jensen PJ, Johnson KR, Wheelock MJ. 1997. Cross-talk between adherens junctions and desmosomes depends on plakoglobin. J Cell Biol 136: 919-934.

Lien WH, Gelfand VI, Vasioukhin V. 2008. $\alpha$-E-catenin binds to dynamitin and regulates dynactin-mediated intracellular traffic. J Cell Biol 183: 989-997.

Ligon LA, Holzbaur EL. 2007. Microtubules tethered at epithelial cell junctions by dynein facilitate efficient junction assembly. Traffic 8: 808-819.

Ligon LA, Karki S, Tokito M, Holzbaur EL. 2001. Dynein binds to $\beta$-catenin and may tether microtubules at adherens junctions. Nat Cell Biol 3: 913-917.

Ling K, Bairstow SF, Carbonara C, Turbin DA, Huntsman DG, Anderson RA. 2007. Type I $\gamma$ phosphatidylinositol phosphate kinase modulates adherens junction and E-cadherin trafficking via a direct interaction with $\mu 1 \mathrm{~B}$ adaptin. J Cell Biol 176: 343-353.

Lock JG, Stow JL. 2005. Rab11 in recycling endosomes regulates the sorting and basolateral transport of E-cadherin. Mol Biol Cell 16: 1744-1755.

Lock JG, Hammond LA, Houghton F, Gleeson PA, Stow JL. 2005. E-cadherin transport from the trans-Golgi network in tubulovesicular carriers is selectively regulated by golgin-97. Traffic 6: 1142-1156.

Lorch JH, Klessner J, Park JK, Getsios S, Wu YL, Stack MS, Green KJ. 2004. Epidermal growth factor receptor inhibition promotes desmosome assembly and strengthens intercellular adhesion in squamous cell carcinoma cells. J Biol Chem 279: 37191-37200.
Lu Z, Ghosh S, Wang Z, Hunter T. 2003. Downregulation of caveolin-1 function by EGF leads to the loss of E-cadherin, increased transcriptional activity of $\beta$-catenin, enhanced tumor cell invasion. Cancer Cell 4: 499-515.

Mao X, Choi EJ, Payne AS. 2009. Disruption of desmosome assembly by monovalent human pemphigus vulgaris monoclonal antibodies. J Invest Dermatol 129: 908-918.

Marcozzi C, Burdett IDJ, Buxton RS, Magee AI. 1998. Coexpression of both types of desmosomal cadherin and plakoglobin confers strong intercellular adhesion. $J$ Cell Sci 111: 495-509.

Mary S, Charrasse S, Meriane M, Comunale F, Travo P, Blangy A, Gauthier-Rouviere C. 2002. Biogenesis of $\mathrm{N}$-cadherin-dependent cell-cell contacts in living fibroblasts is a microtubule-dependent kinesin-driven mechanism. Mol Biol Cell 13: 285-301.

Mege RM, Gavard J, Lambert M. 2006. Regulation of cellcell junctions by the cytoskeleton. Curr Opin Cell Biol 18: $541-548$.

Meng W, Takeichi M. 2009. Adherens junction: molecular architecture and regulation. Cold Spring Harb Perspect Biol 1: 002899.

Meng J-J, Bornslaeger EA, Green KJ, Steinert PM, Ip W. 1997. Two hybrid analysis reveals fundamental differences in direct interactions between desmoplakin and cell type specific intermediate filaments. $J$ Biol Chem 272: 21495-21503.

Meng W, Mushika Y, Ichii T, Takeichi M. 2008. Anchorage of microtubule minus ends to adherens junctions regulates epithelial cell-cell contacts. Cell 135: 948-959.

Michels C, Buchta T, Bloch W, Krieg T, Niessen CM. 2009. Classical cadherins regulate desmosome formation. J Invest Dermatol. Doi: 10.1038/jid.2009.17.

Miranda KC, Joseph SR, Yap AS, Teasdale RD, Stow JL. 2003. Contextual binding of $120 \mathrm{ctn}$ to E-cadherin at the basolateral plasma membrane in polarized epithelia. J Biol Chem 278: 43480-43488.

Miyake Y, Inoue N, Nishimura K, Kinoshita N, Hosoya H, Yonemura S. 2006. Actomyosin tension is required for correct recruitment of adherens junction components and zonula occludens formation. Experimental cell research 312: $1637-1650$.

Miyashita Y, Ozawa M. 2007. A dileucine motif in its cytoplasmic domain directs $\beta$-catenin-uncoupled E-cadherin to the lysosome. J Cell Sci 120: 4395-4406.

Mosesson Y, Mills GB, Yarden Y. 2008. Derailed endocytosis: An emerging feature of cancer. Nat Rev Cancer 8: $835-850$.

Muller EJ, Caldelari R, Posthaus H. 2004. Role of subtilisin-like convertases in cadherin processing or the conundrum to stall cadherin function by convertase inhibitors in cancer therapy. J Mol Histol 35: 263-275.

Muller EJ, Caldelari R, Kolly C, Williamson L, Baumann D, Richard G, Jensen P, Girling P, Delprincipe F, Wyder M, et al. 2006. Consequences of depleted SERCA2-gated calcium stores in the skin. J Invest Dermatol 126: $721-731$. 


\section{K.J. Green et al.}

Niessen CM. 2007. Tight junctions/adherens junctions: Basic structure and function. I Invest Dermatol 127: 2525-2532.

Niessen CM, Gottardi CJ. 2008. Molecular components of the adherens junction. Biochim Biophys Acta 1778: $562-571$.

Noren NK, Niessen CM, Gumbiner BM, Burridge K. 2001. Cadherin engagement regulates Rho family GTPases. $J$ Biol Chem 276: 33305-33308.

North AJ, Chidgey MAJ, Clarke JP, Bardsley WG, Garrod DR. 1996. Distinct desmocollin isoforms occur in the same desmosomes and show reciprocally graded distributions in bovine nasal epidermis. Proc Natl Acad Sci 93: 7701-7705.

Ohsugi M, Hwang SY, Butz S, Knowles BB, Solter D, Kemler R. 1996. Expression and cell membrane localization of catenins during mouse preimplantation development. Dev Dyn 206: 391-402.

Ohsugi M, Larue L, Schwarz H, Kemler R. 1997. Cell-junctional and cytoskeletal organization in mouse blastocysts lacking E-cadherin. Develop Biol 185: 261-271.

Ozawa M, Kemler R. 1990. Correct proteolytic cleavage is required for the cell adhesive function of uvomorulin. $J$ Cell Biol 111: 1645-1650.

Ozawa M, Kemler R. 1998. The membrane-proximal region of the E-cadherin cytoplasmic domain prevents dimerization and negatively regulates adhesion activity. $J$ Cell Biol 142: 1605-1613.

Palacios F, Price L, Schweitzer J, Collard JG, D'souza-Schorey C. 2001. An essential role for ARF6-regulated membrane traffic in adherens junction turnover and epithelial cell migration. Embo J 20: 4973-4986.

Palacios F, Schweitzer JK, Boshans RL, D'souza-Schorey C. 2002. ARF6-GTP recruits Nm23-H1 to facilitate dynamin-mediated endocytosis during adherens junctions disassembly. Nat Cell Biol 4: 929-936.

Palacios F, Tushir JS, Fujita Y, D'souza-Schorey C. 2005. Lysosomal targeting of E-cadherin: A unique mechanism for the down-regulation of cell-cell adhesion during epithelial to mesenchymal transitions. Mol Cell Biol 25: 389-402.

Palovuori R, Sormunen R, Eskelinen S. 2003. SRC-induced disintegration of adherens junctions of madin-darby canine kidney cells is dependent on endocytosis of cadherin and antagonized by Tiam-1. Lab Invest 83: 1901-1915.

Pasdar M, Nelson WJ. 1988. Kinetics of desmosome assembly in Madin-Darby canine kidney epithelial cells: Temporal and spatial regulation of desmoplakin organization and stabilization upon cell-cell contact I. Biochemical analysis. J Cell Biol 106: 677-685.

Pasdar M, Nelson WJ. 1989. Regulation of desmosome assembly in epithelial cells: Kinetics of synthesis, transport, stabilization of desmoglein I, a major protein of the membrane core domain. J Cell Biol 109: 163-177.

Pasdar M, Krzeminski KA, Nelson WJ. 1991. Regulation of desmosome assembly in MDCK epithelial cells: Coordination of membrane core and cytoplasmic plaque domain assembly at the plasma membrane. J Cell Biol 113: 645-655.
Pasdar M, Li Z, Chlumecky V. 1995. Plakoglobin: Kinetics of synthesis, phosphorylation, stability, interactions with desmoglein and E-cadherin. Cell Motil Cytoskel: 258-272.

Paterson AD, Parton RG, Ferguson C, Stow JL, Yap AS. 2003. Characterization of E-cadherin endocytosis in isolated MCF-7 and chinese hamster ovary cells: The initial fate of unbound E-cadherin. J Biol Chem 278: 21050-21057.

Pauken CM, Capco DG. 1999. Regulation of cell adhesion during embryonic compaction of mammalian embryos: Roles for PKC and $\beta$-catenin. Mol Reprod Dev 54: $135-144$.

Penn EJ, Burdett IDJ, Hobson C, Magee AI, Rees DA. 1987. Structure and assembly of desmosome junctions: Biosynthesis and turnover of the major desmosome components of Madin-Darby canine kidney cells in low calcium medium. J Cell Biol 105: 2327-2334.

Perez-Moreno M, Fuchs E. 2006. Catenins: Keeping cells from getting their signals crossed. Dev Cell 11: 601-612.

Perret E, Leung A, Feracci H, Evans E. 2004. Trans-bonded pairs of E-cadherin exhibit a remarkable hierarchy of mechanical strengths. Proc Natl Acad Sci U S A 101: 16472-16477.

Pokutta S, Weis WI. 2007. Structure and mechanism of cadherins and catenins in cell-cell contacts. Annu Rev Cell Dev Biol 23: 237-261.

Pokutta S, Drees F, Yamada S, Nelson WJ, Weis WI. 2008. Biochemical and structural analysis of $\alpha$-catenin in cellcell contacts. Biochem Soc Trans 36: 141-147.

Raich WB, Agbunag C, Hardin J. 1999. Rapid epithelialsheet sealing in the Caenorhabditis elegans embryo requires cadherin-dependent filopodial priming. Curr Biol 9: 1139-1146.

Riethmacher D, Brinkmann V, Birchmeier C. 1995. A targeted mutation in the mouse E-cadherin gene results in defective preimplantation development. Proc Natl Acad Sci 92: 855-859.

Ruiz P, Brinkmann V, Ledermann B, Behrend M, Grund C, Thalhammer C, Vogel F, Birchmeier C, Gunthert U, Franke WW, et al. 1996. Targeted mutation of plakoglobin in mice reveals essential functions of desmosomes in the embryonic heart. J Cell Biol 135: 215-225.

Sahai E, Marshall CJ. 2002. ROCK and Dia have opposing effects on adherens junctions downstream of Rho. Nat Cell Biol 4: 408-415.

Sakuntabhai A, Ruiz-Perez V, Carter S, Jacobsen N, Burge S, Monk S, Smith M, Munro CS, O’Donovan M, Craddock $\mathrm{N}$, et al. 1999. Mutations in ATP2A2, encoding a Ca2+ pump, cause Darier disease [see comments]. Nat Genet 21: 271-277.

Sato M, Aoyama Y, Kitajima Y. 2000. Assembly pathway of desmoglein 3 to desmosomes and its perturbation by pemphigus vulgaris-IgG in cultured keratinocytes, as revealed by time- lapsed labeling immunoelectron microscopy [In Process Citation]. Lab Invest 80: $1583-1592$.

Schneider SQ, Finnerty JR, Martindale MQ. 2003. Protein evolution: Structure-function relationships of the oncogene $\beta$-catenin in the evolution of multicellular animals. J Exp Zoolog B Mol Dev Evol 295: 25-44. 
Sefton M, Johnson MH, Clayton L. 1992. Synthesis and phosphorylation of uvomorulin during mouse early development. Development 115: 313-318.

Shapiro L, Weis WI. 2009. Structure and biochemistry of cadherins and catenins. Cold Spring Harb Perspect Biol 1: a003053.

Shapiro L, Fannon AM, Kwong PD, Thompson A, Lehmann MS, Grubel G, Legrand J-F, Als-Nielson J, Colman DR, Hendrickson WA. 1995. Structural basis of cell-cell adhesion by cadherins. Nature 374: 327-337.

Shaw RM, Fay AJ, Puthenveedu MA, von Zastrow M, Jan YN, Jan LY. 2007. Microtubule plus-end-tracking proteins target gap junctions directly from the cell interior to adherens junctions. Cell 128: 547-560.

Shen Y, Hirsch DS, Sasiela CA, Wu WJ. 2008. Cdc42 regulates E-cadherin ubiquitination and degradation through an epidermal growth factor receptor to Src-mediated pathway. J Biol Chem 283: 5127-5137.

Sheu H-M, Kitajima Y, Yaoita H. 1989. Involvement of protein kinase $\mathrm{C}$ in translocation of desmoplakins from cytosol to plasma membrane during desmosome formation in human squamous cell carcinoma cells grown in low to normal calcium concentration. Exp Cell Res 185: $176-190$.

Shore EM, Nelson WJ. 1991. Biosynthesis of the cell adhesion molecule uvomorulin (E-cadherin) in MadinDarby Canine Kidney epithelial cells. J Biol Chem 266: 19672-19680.

Stappenbeck TS, Lamb JA, Corcoran CM, Green KJ. 1994. Phosphorylation of the desmoplakin $\mathrm{COOH}$ terminus negatively regulates its interaction with keratin intermediate filament networks. $J$ Biol Chem 269: 29351-29354.

Stehbens SJ, Paterson AD, Crampton MS, Shewan AM, Ferguson C, Akhmanova A, Parton RG, Yap AS. 2006. Dynamic microtubules regulate the local concentration of E-cadherin at cell-cell contacts. J Cell Sci 119: 1801-1811.

Stehbens SJ, Akhmanova A, Yap AS. 2009. Microtubules and cadherins: A neglected partnership. Front Biosci 14: 3159-3167.

Stemmler MP. 2008. Cadherins in development and cancer. Mol Biosyst 4: 835-850.

Suyama K, Shapiro I, Guttman M, Hazan RB. 2002. A signaling pathway leading to metastasis is controlled by $\mathrm{N}$-cadherin and the FGF receptor. Cancer Cell 2: 301-314.

Syed SE, Trinnaman B, Martin S, Major S, Hutchinson J, Magee AI. 2002. Molecular interactions between desmosomal cadherins. Biochem J 362: 317-327.

Tachibana K, Nakanishi H, Mandai K, Ozaki K, Ikeda W, Yamamoto Y, Nagafuchi A, Tsukita S, Takai Y. 2000. Two cell adhesion molecules, nectin and cadherin, interact through their cytoplasmic domain-associated proteins. J Cell Biol 150: 1161-1176.

Tai CY, Mysore SP, Chiu C, Schuman EM. 2007. Activity-regulated N-cadherin endocytosis. Neuron 54: 771-785.

Taniguchi T, Miyazaki M, Miyashita Y, Arima T, Ozawa M. 2005. Identification of regions of $\alpha$-catenin required for desmosome organization in epithelial cells. Int $\mathrm{J} \mathrm{Mol}$ Med 16: 1003-1008.

Teng J, Rai T, Tanaka Y, Takei Y, Nakata T, Hirasawa M, Kulkarni AB, Hirokawa N. 2005. The KIF3 motor transports N-cadherin and organizes the developing neuroepithelium. Nat Cell Biol 7: 474-482.

Tinkle CL, Pasolli HA, Stokes N, Fuchs E. 2008. New insights into cadherin function in epidermal sheet formation and maintenance of tissue integrity. Proc Natl Acad Sci U S A 105: 15405-15410.

Torres M, Stoykova A, Huber O, Chowdhury K, Bonaldo P, Mansouri A, Butz S, Kemler R, Gruss P. 1997. An $\alpha$-E-catenin gene trap mutation defines its function in preimplantation development. Proc Natl Acad Sci U S A 94: 901-906.

Troyanovsky RB, Sokolov E, Troyanovsky SM. 2003. Adhesive and lateral E-cadherin dimers are mediated by the same interface. Mol Cell Biol 23: 7965-7972.

Troyanovsky RB, Sokolov EP, Troyanovsky SM. 2006. Endocytosis of cadherin from intracellular junctions is the driving force for cadherin adhesive dimer disassembly. Mol Biol Cell 17: 3484-3493.

Troyanovsky RB, Laur O, Troyanovsky SM. 2007. Stable and unstable cadherin dimers: Mechanisms of formation and roles in cell adhesion. Mol Biol Cell 18: 4343-4352.

Tselepis C, Chidgey M, North A, Garrod D. 1998. Desmosomal adhesion inhibits invasive behavior. Proc Natl Acad Sci 95: 8064-8069.

Tunggal JA, Helfrich I, Schmitz A, Schwarz H, Gunzel D, Fromm M, Kemler R, Krieg T, Niessen CM. 2005. E-cadherin is essential for in vivo epidermal barrier function by regulating tight junctions. Embo $J$ 24: 1146-1156.

Vaezi A, Bauer C, Vasioukhin V, Fuchs E. 2002. Actin cable dynamics and Rho/Rock orchestrate a polarized cytoskeletal architecture in the early steps of assembling a stratified epithelium. Dev Cell 3: 367-381.

Vasioukhin V, Bauer C, Yin M, Fuchs E. 2000. Directed actin polymerization is the driving force for epithelial cell-cell adhesion. Cell 100: 209-219.

Vasioukhin V, Bauer C, Degenstein L, Wise B, Fuchs E. 2001a. Hyperproliferation and defects in epithelial polarity upon conditional ablation of $\alpha$-catenin in skin. Cell 104: 605-617.

Vasioukhin V, Bowers E, Bauer C, Degenstein L, Fuchs E. 2001b. Desmoplakin is essential in epidermal sheet formation. Nat Cell Biol 3: 1076-1085.

Vestweber D, Gossler A, Boller K, Kemler R. 1987. Expression and distribution of cell adhesion molecule uvomorulin in mouse preimplantation embryos. Dev Biol 124: 451-456.

Wahl JK 3rd. 2005. A role for plakophilin-1 in the initiation of desmosome assembly. J Cell Biochem 96: 390-403.

Wallis S, Lloyd S, Wise I, Ireland G, Fleming TP, Garrod D. 2000. The $\alpha$ isoform of protein kinase $\mathrm{C}$ is involved in signaling the response of desmosomes to wounding in cultured epithelial cells. Mol Biol Cell 11: 1077-1092.

Wang Q, Chen XW, Margolis B. 2007. PALS1 regulates E-cadherin trafficking in mammalian epithelial cells. Mol Biol Cell 18: 874-885. 


\section{K.J. Green et al.}

Warren S, Nelson WJ. 1987. Nonmitogenic morphoregulatory action of pp60src on multicellular epithelial structures. Mol Cell Biol 7: 1326-1337.

Waschke J, Bruggeman P, Baumgartner W, Zillikens D, Drenckhahn D. 2005. Pemphigus foliaceus IgG causes dissociation of desmoglein 1-containing junctions without blocking desmoglein 1 transinteraction. J Clin Invest 115: 3157-3165.

Waschke J, Spindler V, Bruggeman P, Zillikens D, Schmidt G, Drenckhahn D. 2006. Inhibition of $\rho$ A activity causes pemphigus skin blistering. J Cell Biol 175: 721-727.

Watabe M, Nagafuchi A, Tsukita S, Takeichi M. 1994. Induction of polarized cell-cell association and retardation of growth by activation of the E-cadherincatenin adhesion system in a dispersed carcinoma line. J Cell Biol 127: 247-256.

Waterman-Storer CM, Salmon WC, Salmon ED. 2000 Feedback interactions between cell-cell adherens junctions and cytoskeletal dynamics in newt lung epithelial cells [In Process Citation]. Mol Biol Cell 11: 2471-2483.

Watt FM, Mattey DL, Garrod DR. 1984. Calcium-induced reorganization of desmosomal components in cultured human keratinocytes. J Cell Biol 99: 2211-2215.

Wilanowski T, Caddy J, Ting SB, Hislop NR, Cerruti L, Auden A, Zhao LL, Asquith S, Ellis S, Sinclair R, et al. 2008. Perturbed desmosomal cadherin expression in grainy head-like 1-null mice. Embo J 27: 886-897.

Wildenberg GA, Dohn MR, Carnahan RH, Davis MA, Lobdell NA, Settleman J, Reynolds AB. 2006. p120-catenin and p190RhoGAP regulate cell-cell adhesion by coordinating antagonism between Rac and Rho. Cell 127: 1027-1039.

Windoffer R, Borchert-Stuhltrager M, Leube RE. 2002. Desmosomes: Interconnected calcium-dependent structures of remarkable stability with significant integral membrane protein turnover. J Cell Sci 115: 1717-1732.

Wollner DA, Krzeminski KA, Nelson WJ. 1992. Remodeling the cell surface distribution of membrane proteins during the development of epithelial cell polarity. J Cell Biol 116: 889-899.

Xiao K, Allison DF, Buckley KM, Kottke MD, Vincent PA, Faundez V, Kowalczyk AP. 2003. Cellular levels of p120 catenin function as a set point for cadherin expression levels in microvascular endothelial cells. J Cell Biol 163: 535-545.

Xiao K, Garner J, Buckley KM, Vincent PA, Chiasson CM, Dejana E, Faundez V, Kowalczyk AP. 2005. p120Catenin regulates clathrin-dependent endocytosis of VE-cadherin. Mol Biol Cell 16: 5141-5151.

Yamada S, Nelson WJ. 2007. Localized zones of Rho and Rac activities drive initiation and expansion of epithelial cellcell adhesion. J Cell Biol 178: 517-527.

Yamada S, Pokutta S, Drees F, Weis WI, Nelson WJ. 2005. Deconstructing the cadherin-catenin-actin complex. Cell 123: 889-901.

Yamamura R, Nishimura N, Nakatsuji H, Arase S, Sasaki T. 2008. The interaction of JRAB/MICAL-L2 with Rab8 and Rab13 coordinates the assembly of tight junctions and adherens junctions. Mol Biol Cell 19: 971-983.

Yap AS, Crampton MS, Hardin J. 2007. Making and breaking contacts: The cellular biology of cadherin regulation. Curr Opin Cell Biol 19: 508-514.

Yokouchi M, Saleh MA, Kuroda K, Hachiya T, Stanley JR, Amagai M, Ishii K. 2009. Pathogenic epitopes of autoantibodies in pemphigus reside in the aminoterminal adhesive region of desmogleins which are unmasked by proteolytic processing of prosequence. J Invest Dermatol doi: 10.1038/jid.2009.61.

Yonemura S, Itoh M, Nagafuchi A, Tsukita S. 1995. Cell-to-cell adherens junction formation and actin filament organization: Similarities and differences between non-polarized fibroblasts and polarized epithelial cells. J Cell Sci 108: 127-142.

Zandy NL, Playford M, Pendergast AM. 2007. Abl tyrosine kinases regulate cell cell adhesion through Rho GTPases. Proc Natl Acad Sci 104: 17686-17691.

Zhang J, Betson M, Erasmus J, Zeikos K, Bailly M, Cramer LP, Braga VM. 2005. Actin at cell-cell junctions is composed of two dynamic and functional populations. $J$ Cell Sci 118: 5549-5562.

Zhang Y, Sivasankar S, Nelson WJ, Chu S. 2009. Resolving cadherin interactions and binding cooperativity at the single-molecule level. Proc Natl Acad Sci 106: 109-114. 


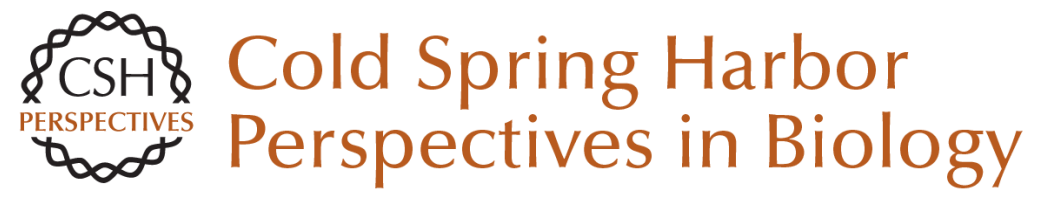

\section{Intercellular Junction Assembly, Dynamics, and Homeostasis}

Kathleen J. Green, Spiro Getsios, Sergey Troyanovsky and L.M. Godsel

Cold Spring Harb Perspect Biol 2010; doi: 10.1101/cshperspect.a000125 originally published online August 26, 2009

\section{Subject Collection Cell-Cell Junctions}

Vascular Endothelial (VE)-Cadherin, Endothelial Adherens Junctions, and Vascular Disease Maria Grazia Lampugnani, Elisabetta Dejana and Costanza Giampietro

Adherens Junctions and Desmosomes Coordinate Mechanics and Signaling to Orchestrate Tissue Morphogenesis and Function: An Evolutionary Perspective Matthias Rübsam, Joshua A. Broussard, Sara A. Wickström, et al.

Cell-Cell Contact and Receptor Tyrosine Kinase Signaling Christine Chiasson-MacKenzie and Andrea I. McClatchey

Hold Me, but Not Too Tight--Endothelial Cell-Cell Junctions in Angiogenesis Anna Szymborska and Holger Gerhardt

\section{Connexins and Disease}

Mario Delmar, Dale W. Laird, Christian C. Naus, et al.

\section{Cell Junctions in Hippo Signaling}

Ruchan Karaman and Georg Halder

Loss of E-Cadherin-Dependent Cell-Cell Adhesion and the Development and Progression of Cancer Heather C. Bruner and Patrick W.B. Derksen
Signaling by Small GTPases at Cell-Cell Junctions: Protein Interactions Building Control and Networks Vania Braga

Making Connections: Guidance Cues and Receptors at Nonneural Cell-Cell Junctions Ian V. Beamish, Lindsay Hinck and Timothy E. Kennedy

The Cadherin Superfamily in Neural Circuit Assembly James $D$. Jontes

Mechanosensing and Mechanotransduction at Cell-Cell Junctions Alpha S. Yap, Kinga Duszyc and Virgile Viasnoff

Beyond Cell-Cell Adhesion: Sensational

Cadherins for Hearing and Balance Avinash Jaiganesh, Yoshie Narui, Raul Araya-Secchi, et al.

Cell-Cell Junctions Organize Structural and Signaling Networks Miguel A. Garcia, W. James Nelson and Natalie Chavez

Cell Biology of Tight Junction Barrier Regulation and Mucosal Disease Aaron Buckley and Jerrold R. Turner

For additional articles in this collection, see http://cshperspectives.cshlp.org/cgi/collection/

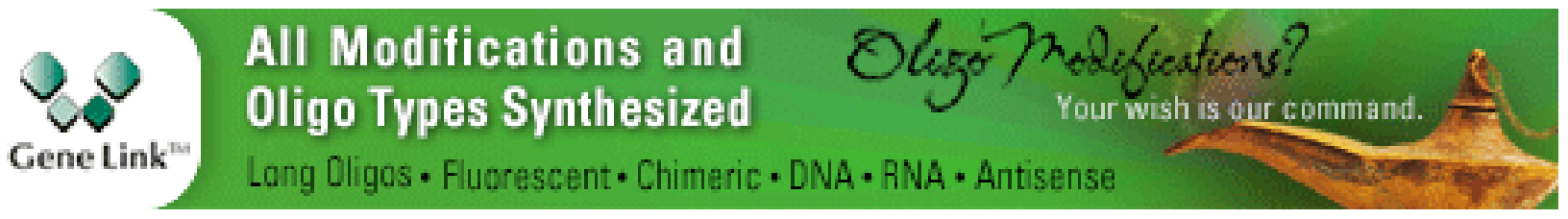


Desmosomes and Intermediate Filaments: Their Consequences for Tissue Mechanics Mechthild Hatzfeld, René Keil and Thomas M. Magin
Integration of Cadherin Adhesion and

Cytoskeleton at Adherens Junctions

René Marc Mège and Noboru Ishiyama

For additional articles in this collection, see http://cshperspectives.cshlp.org/cgi/collection/

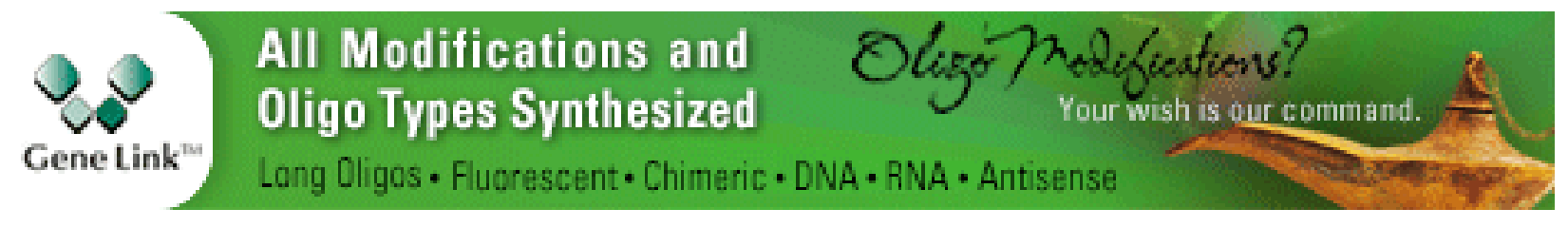

Copyright @ 2010 Cold Spring Harbor Laboratory Press; all rights reserved 